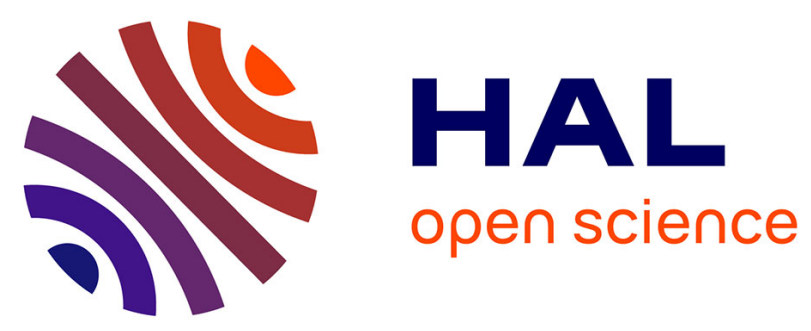

\title{
Nanocrystals FAU-X monoliths as highly efficient microreactors for cesium capture in continuous flow
}

Youcef Didi, Bilel Said, Matthieu Micolle, Thomas Cacciaguerra, Didier Cot, Amine Geneste, François Fajula, Anne Galarneau

\section{- To cite this version:}

Youcef Didi, Bilel Said, Matthieu Micolle, Thomas Cacciaguerra, Didier Cot, et al.. Nanocrystals FAU-X monoliths as highly efficient microreactors for cesium capture in continuous flow. Microporous and Mesoporous Materials, 2019, 285, pp.185-194. 10.1016/j.micromeso.2019.05.012 . hal-02138025

\section{HAL Id: hal-02138025 \\ https://hal.science/hal-02138025}

Submitted on 25 Nov 2020

HAL is a multi-disciplinary open access archive for the deposit and dissemination of scientific research documents, whether they are published or not. The documents may come from teaching and research institutions in France or abroad, or from public or private research centers.
L'archive ouverte pluridisciplinaire HAL, est destinée au dépôt et à la diffusion de documents scientifiques de niveau recherche, publiés ou non, émanant des établissements d'enseignement et de recherche français ou étrangers, des laboratoires publics ou privés. 


\title{
Nanocrystals FAU-X monoliths as highly efficient microreactors for cesium capture in continuous flow
}

\author{
Youcef Didi a, Bilel Said ${ }^{\text {a }}$, Matthieu Micolle ${ }^{\text {a }}$, Thomas Cacciaguerra ${ }^{\text {a }}$, Didier \\ $\operatorname{Cot}^{\mathrm{b}}$, Amine Geneste ${ }^{\mathrm{a}}$, Francois Fajula ${ }^{\mathrm{a}}$, Anne Galarneau ${ }^{\mathrm{a} *}$ \\ a Institut Charles Gerhardt Montpellier, UMR 5253 CNRS - Univ Montpellier - ENSCM, ENSCM, 240 avenue \\ du Professeur Emile Jeanbrau, 34296 Montpellier Cedex 5, France. \\ ${ }^{\mathrm{b}}$ IEM (Institut Europeen des Membranes), UMR 5635 CNRS - Univ Montpellier - ENSCM, Univ Montpellier,
}

*Corresponding author: E-mail address: anne.galarneau@enscm.fr (A. Galarneau)

\begin{abstract}
The performances of binderless FAU-X monoliths $(0.5 \times 3 \mathrm{~cm})$ build of nanocrystals featuring hierarchical trimodal porosity (micro-/meso-/macroporosity) in decontamination Cs-containing effluents have been evaluated. They have been compared to those obtained with newly synthesized FAU-X particles $(1 \mathrm{~mm})$ build with nanocrystals. Data have been confronted to those recently reported for a benchmark reference $\mathrm{Cs}^{+}$adsorbent Sorbmatech ${ }^{\circledR}$, based on copper hexacyanoferrate nanoparticles $(15 \mathrm{~nm})$ immobilized into mesoporous silica particles $(250-500 \mu \mathrm{m})\left(\mathrm{Cu}-\mathrm{HCF} @ \mathrm{SiO}_{2}\right)$. FAU-X monoliths show high rate of adsorption in batch in less than 2 min, much faster than $\mathrm{Cs}^{+}$adsorption in FAU-X particles (60 min). This result highlights the importance of a homogeneous macropore network in adsorbents to enhance mass transport and access to the zeolite active sites. FAU-X monoliths with $20 \mu \mathrm{m}$ macropore diameter have been used in continuous flow experiments for sequestering $\mathrm{Cs}^{+}(0.5 \mathrm{mmol} / \mathrm{L})$ in mineral drinking water containing competing cations $\left(\mathrm{Ca}^{2+}\right.$, $\mathrm{Mg}^{2+}, \mathrm{Na}^{+}, \mathrm{K}^{+}$) with flow rates of 0.5 to $1 \mathrm{~mL} / \mathrm{min}$, corresponding to Darcy rates of $1.5-3$ $\mathrm{m} / \mathrm{h}$. FAU-X monoliths are very efficient for $\mathrm{Cs}^{+}$removal and show ideal steep breakthrough curves characteristic of fast diffusion. FAU-X monoliths are as excellent as $\mathrm{Cu}-\mathrm{HCF} @ \mathrm{SiO}_{2}$ and could represent an alternative adsorbent for safer processes, avoiding the handling of powders or particles. Above all, this study reveals the unique hydrodynamic behavior of FAU-X monoliths and opens the route for process intensification using FAU-X in continuous flow.
\end{abstract}


KEYWORDS: 13X; binderless FAU-X; Cs adsorption; monolith; water treatment.

\section{Introduction}

Zeolites are excellent cation-exchange adsorbents. Zeolites with $\mathrm{Si} / \mathrm{Al}$ ratio of 1 as LTA or close to 1 as FAU-X $(1<\mathrm{Si} / \mathrm{Al}<1.5)$ have the highest exchange capacity with 5.4 and $4.8 \mathrm{meq} / \mathrm{g}$, respectively. One interesting application of zeolites is the capture of radioactive ions coming from management of effluents produced by nuclear industry or from nuclear accidents such as contaminated sweet and sea waters after Fukushima disaster. There is a substantial demand for efficient methods to decontaminate the radionuclide-contaminated water, to maintain captive the contamination into an adsorbent easier to manage and to decrease the amount of contaminated adsorbents to be stored. ${ }^{137} \mathrm{Cs}$ and ${ }^{90} \mathrm{Sr}$ are among of the most abundant and hazardous radionuclides because they are found in many types of wastes and have a relatively long half-life (30 years). Previously, we have shown that LTA monoliths with hierarchical macro-/meso-/microporosity with uniform and homogeneous macropore networks, which skeleton is built of nanocrystals [1] were excellent for $\mathrm{Sr}^{2+}$ capture in continuous flow with 4200 bed volumes (BV) efficiently treated at a Darcy flow rate of $1 \mathrm{~m} / \mathrm{h}$ [2]. This result highlights the positive impact of multiscale pore architecture engineering of a zeolitic adsorbent for process intensification: macropores allow uniform mass transport of solutes with low pressure drop [3] while mesopores lead to faster ionic transport [4] and more efficient crystal use, both in batch and flow modes. LTA monoliths offer the possibility to develop safer processes, with no powder to handle, and to decrease the volume of adsorbents to store. LTA has been demonstrated to be the most selective zeolite for $\mathrm{Sr}^{2+}$ adsorption with the highest cation-exchange capacity [5]. However for $\mathrm{Cs}^{+}$adsorption for sequestering radionuclides, many adsorbents as zeolites (CHA, MOR, FAU-X) and essentially hexacyanoferrates (HCF)-based adsorbents have been tested, all showing advantages and drawbacks [6].

Among zeolites the most used for selective extraction of $\mathrm{Cs}^{+}$is chabazite (CHA) [7]. Featuring $\mathrm{Si} / \mathrm{Al}=1.5, \mathrm{CHA}$ also known as Hershelite, has a high selectivity towards $\mathrm{Cs}^{+}\left(\mathrm{Cs}^{+}\right.$ $>\mathrm{K}^{+}>\mathrm{Na}^{+}>\mathrm{Li}^{+}, \mathrm{Ba}^{2+}>\mathrm{Sr}^{2+}>\mathrm{Ca}^{2+}, \mathrm{Mg}^{2+}$ ) with an exchange capacity of $2.4 \mathrm{meq} / \mathrm{g}$, which is higher than other tested zeolites as stilbite and heulandite [8]. However, the kinetics of adsorption are quite slow and maximum capacities of adsorption were reached in $30 \mathrm{~min}$ for 
CHA (particles grinded between $150-355 \mu \mathrm{m})$. FAU-X is also selective for $\mathrm{Cs}^{+}\left(\mathrm{Ag}^{+}>>\mathrm{Cs}^{+}\right.$ $>\mathrm{K}^{+}>\mathrm{Na}^{+}>\mathrm{Li}^{+}$) and will be tested in this study for $\mathrm{Cs}^{+}$capture in mineral drinking water containing many competing ions. FAU-X possesses a tridimentional network build with two kinds of cages: sodalite cages and supercages. A supercage has a spherical geometry and comes from a building of 8 sodalite cages linked by hexagonal prisms. The supercage diameter is $1.3 \mathrm{~nm}$. The access to the supercage is through 12 windows of $7.4 \mathrm{~nm}$ diameter. The cations occupy three positions in FAU-X. Sites I and I' are on the hexagonal prism faces between the sodalite cages. They can contain up to $16 \mathrm{Na}^{+}(1$ per each 16 prims or 2 per each 8 sodalite cages). Sites II and II' are on the opening of the supercage near to the 6-ring sodalite cage and can be occupied by $32 \mathrm{Na}^{+}$. Sites III are on the walls of the supercage and can accept up to $37 \mathrm{Na}^{+}$; these cations are in constant motion. The $\mathrm{Na}^{+}$cations in sites II and III (in the supercage) are the most accessible and will be first exchanged [9,10]. FAU-X zeolites possess $192 \mathrm{Al}$ and $\mathrm{Si}$ tetrahedra per unit cell and for $\mathrm{Si} / \mathrm{Al}=1.26$ the general formula is $\mathrm{Na}_{85}\left[\left(\mathrm{AlO}_{3}\right)_{85}\left(\mathrm{SiO}_{2}\right)_{107}\right], 264 \mathrm{H}_{2} \mathrm{O}$ with $3 \mathrm{H}_{2} \mathrm{O} / \mathrm{Na}^{+}$. The theoretical cation-exchange capacity (CEC) is $4.83 \mathrm{meq} / \mathrm{g}$. However the $16 \mathrm{Na}^{+}$in sodalite cages are not exchangeable by $\mathrm{Cs}^{+}$, which decreases the theoretical CEC to $3.92 \mathrm{meq} / \mathrm{g}$. Furthermore, when $40 \% \mathrm{of} \mathrm{Na}^{+}$are exchanged, the selectivity of FAU-X changes to $\mathrm{Ag}^{+}>>\mathrm{Na}^{+}>\mathrm{K}^{+}>\mathrm{Cs}^{+}>\mathrm{Li}^{+}[10]$. This leads to a decrease of theoretical CEC to $1.93 \mathrm{meq} / \mathrm{g}$. Higher $\mathrm{Si} / \mathrm{Al}$ ratio as for $\mathrm{FAU}-\mathrm{X}$ with $\mathrm{Si} / \mathrm{Al}=$ 1.5 results in a lower of CEC (1.66 meq/g).

FAU-X showed the highest capacity of $\mathrm{Cs}^{+}$adsorption in radioactive contaminated water among zeolites in the following range: FAU-X $>$ LTA $>$ MOR $>$ ZSM-5 [11]. The rate of adsorption is quite slow as the maximum uptake is reached in 50 min for commercial zeolites (grinded in between $250-300 \mu \mathrm{m}$ ). FAU-X, LTA and MOR have been used to decontaminate real radioactive effluents in continuous flow. Zeolites were inactive in one effluent and active in another one, with the best efficient adsorption for MOR [11]. Zeolites are therefore effluents dependent. Among LTA, P, FAU-X, FAU-Y, MOR zeolites, MOR has shown the highest selectivity for $\mathrm{Cs}^{+}$with no correlation with the cationic exchange capacity [5]. Natural MOR has been used as inexpensive $\mathrm{Cs}^{+}$adsorbate in Fukushima and tested to form a glassy phase at high temperature $\left(1000{ }^{\circ} \mathrm{C}\right.$ or $900{ }^{\circ} \mathrm{C}$ with $\left.\mathrm{Na}_{2} \mathrm{CO}_{3}\right)$ for long-term storage [12]. Zeolites have been proposed to be used in series with columns filled with HexaCyanoFerrate $(\mathrm{HCF})$ as $\mathrm{K}_{2} \mathrm{FeCu}(\mathrm{CN})_{6}(\mathrm{Cu}-\mathrm{HCF})$ immobilized on polymeric polyacrylic fibers to reach a high factor of decontamination [13]. However polymers have revealed stability problems under irradiation at the opposite of zeolites or inorganic materials. 
$\mathrm{Cu}-\mathrm{HCF}$ is the most selective material to extract $\mathrm{Cs}^{+}$with an exchange capacity of $0.75 \mathrm{meq} / \mathrm{g}$ for micronic particles and $1.2 \mathrm{meq} / \mathrm{g}$ for nanoparticles featuring fast kinetics [14]. However due to their small grain size they cannot be used in fixed bed columns because of pressure loss and clogging. Their slow adsorption kinetics in micronic powder form is also problematic for column-based processes. To overcome these drawbacks HCF have been immobilized on different supports [6,15]. As an example, $\mathrm{Cu}-\mathrm{HCF}$ has been adsorbed of cotton fibers of $1 \mu \mathrm{m}$ wound around Inox tubes, which allowed to treat efficiently contaminated seawater in Australia [16]. Recently, nanoparticles of $\mathrm{Cu}-\mathrm{HCF}$ have been immobilized in silica particles $(250-500 \mu \mathrm{m})$ and have revealed fast $\mathrm{Cs}^{+}$adsorption kinetics in batch in less than 5 min [17] and in continuous flow with steep breakthrough curves [18] with an exchange capacity of 0.2-0.3 meq/g. These new adsorbents $\mathrm{K}_{2} \mathrm{FeCu}(\mathrm{CN})_{6} @ \mathrm{SiO}_{2}(\mathrm{Cu}-$ $\mathrm{HCF} @ \mathrm{SiO}_{2}$ ) with excellent properties towards $\mathrm{Cs}^{+}$decontamination in flow processes are developed by CEA and Orano and commercialized by CTI (France) under the name Sorbmatech ${ }^{\circledR}$. Data recently reported for this material $\left(\mathrm{Cu}-\mathrm{HCF} @ \mathrm{SiO}_{2}\right)$ [17,18] will be confronted to those obtained during the present study.

By modeling, it was demonstrated the importance of the shaping of the adsorbents for cations capture. Monolithic structures with hierarchical porosity are highly recommended as perspective materials for efficient cations sequestering: with macropores for flow through processes, mesopores for a better access to the active phase, which should feature micropores for better sequestering and shaped as nanoparticles with the smallest size as possible for a maximum use of its adsorption capacity [14].

Very recently, we have succeeded in the synthesis of FAU-X monoliths built of nanocrystals [19] featuring a similar pore architecture as LTA monoliths [1,2]. These FAU-X monoliths were obtained by a double pseudomorphic transformation of silica monoliths resulting from a combination of spinodal decomposition and sol-gel process leading to adjustable macropore diameter between 2 and $20 \mu \mathrm{m}$. This kind of silica monoliths functionalized by different active phases and other monoliths as $\mathrm{TiO}_{2}[20]$ have demonstrated high potentiality for process intensification in catalysis and in adsorption with higher productivity in comparison to packed-bed materials [21]. For FAU-X monoliths synthesis, silica monoliths were first transformed into silica-alumina monoliths at low $\mathrm{NaOH}$ concentration and the resulting silica-alumina monoliths were then transformed into FAU-X monoliths at high $\mathrm{NaOH}$ concentration [19]. FAU-X monoliths feature adjustable macropores (from 2 to $20 \mu \mathrm{m}$, similarly as parent silica monoliths) with a macropore volume of $1 \mathrm{~mL} / \mathrm{g}$, a secondary porosity $(30-1000 \mathrm{~nm})$ of $0.4 \mathrm{~mL} / \mathrm{g}$ in between nanocrystals and FAU-X 
nanocrystals with two populations of sizes 100/200 - 400/500 nm. These monoliths present therefore all the characteristics for process intensification as ionic adsorbents.

The hierarchical structures of FAU-X monoliths with 3 levels of porosity composed of nanocrystals should be highly suitable for fast kinetics in adsorption processes, as demonstrated by modeling [14]. In this study, $\mathrm{Cs}^{+}$adsorption has been performed in batch and in continuous flow using deionized and mineral drinking waters containing competing cations. The adsorption properties of FAU-X monoliths featuring nanocrystals will be compared to those of FAU-X monoliths featuring microcrystals and FAU-X particles $(1 \mathrm{~mm})$ built with nanocrystals. Data will be confronted to those reported recently in literature for the Sorbmatech ${ }^{\circledR}$ benchmark material $\left(\mathrm{K}_{2} \mathrm{FeCu}(\mathrm{CN})_{6}\right.$ immobilized in silica particles of $250-500$ $\mu \mathrm{m}$, hereafter $\mathrm{Cu}-\mathrm{HCF} @ \mathrm{SiO}_{2}[15,17,18]$

\section{Materials and methods}

\subsection{FAU-X monoliths synthesis}

First silica monoliths have been prepared. Tetraethylorthosilicate (TEOS, Aldrich) (20 $\mathrm{g})$ is left at $-19^{\circ} \mathrm{C}$ for $1 \mathrm{~h}$. In parallel, water $(24.560 \mathrm{~g})$ and then $(2.313 \mathrm{~g})$ nitric acid $(68 \%)$ are added in a $100 \mathrm{~mL}$ Erlenmeyer. The mixture is stirred for $5 \mathrm{~min}$ at room temperature. Polyethylene oxide (Sigma) (PEO $20 \mathrm{kDa}$ for Monolith-FAU-X-1 and PEO $35 \mathrm{kDa}$ for Monolith-FAU-X-2) (2.534 g) is added to the mixture and stirred at room temperature until having complete dissolution of the polymer (around $15 \mathrm{~min}$ ). The mixture is left $15 \mathrm{~min}$ at $19^{\circ} \mathrm{C}$ in the freezer to cool down the solution without freezing. The flask is then placed in an ice bath and stirred. TEOS (coming from the freezer) is directly added to the slurry and the solution is stirred for $30 \mathrm{~min}$ at $500 \mathrm{rpm}$ to homogenize the mixture and obtain a translucent solution. The final composition of the mixture in molar ratio is: $1 \mathrm{Si} / 0.60 \mathrm{EO}$ unit / 0.26 $\mathrm{HNO}_{3} / 14.21 \mathrm{H}_{2} \mathrm{O}$. Polyvinyl chloride (PVC) tubes of $8 \mathrm{~mm}$ diameter and $10 \mathrm{~cm}$ length are closed on one side with a cap, sealed with parafilm and kept at $-19^{\circ} \mathrm{C}$ in the freezer. The tubes are taken from the freezer and filled with the mixture of the ice bath. The tubes are then closed by caps and sealed with parafilm and left in water bath at $40^{\circ} \mathrm{C}$ for 3 days. The phase separation and the sol-gel process take place during this time. Monoliths are then removed from the tube molds and placed in $1 \mathrm{~L}$ water bath at room temperature. Water is changed every 30 minutes until reaching a neutral $\mathrm{pH}$ ( $\sim 4$ washings are necessary). The monoliths are then immersed in $1 \mathrm{~L}$ aqueous ammonia $(0.1 \mathrm{M})$ in a polypropylene bottle and left in an oven at $40{ }^{\circ} \mathrm{C}$ for $24 \mathrm{~h}$. Resulting monoliths are placed in a water bath and water is changed every 
30 min until neutral $\mathrm{pH}$. The monoliths are then dried at room temperature during 1 night and calcined at $550^{\circ} \mathrm{C}$ for $8 \mathrm{~h}$ (with a heating rate of $2^{\circ} \mathrm{C} / \mathrm{min}$ from 25 to $550^{\circ} \mathrm{C}$ ) under air to remove remaining PEO. Silica monoliths of $6 \mathrm{~mm}$ diameter and $10 \mathrm{~cm}$ length have been obtained and have been cut at the desired lengths $(3$ or $5 \mathrm{~cm}$ ) with a knife for the further pseudomorphic transformations.

Secondly, silica-alumina monoliths have been prepared. Silica-alumina monoliths are obtained by the pseudomorphic transformation of silica monoliths in mild basic medium $([\mathrm{NaOH}]=0.24 \mathrm{M})$ by adding a source of alumina $\left(\mathrm{NaAlO}_{2}\right.$, Carlo Erba $)$ in the synthesis. The synthesis composition is given for 2 calcined silica monoliths of $5 \mathrm{~cm}$ length and $6 \mathrm{~mm}$ diameter $(800 \mathrm{mg})$. In a beaker of $50 \mathrm{~mL}, 0.074 \mathrm{~g}$ of NaOH is dissolved in $7.656 \mathrm{~g}$ of water and $1.224 \mathrm{~g}$ of sodium aluminate $\left(\mathrm{NaAlO}_{2}\right)$ is added and stirred for $15 \mathrm{~min}$. The molar composition of the system is: $1 \mathrm{SiO}_{2} / 0.14 \mathrm{NaOH} / 1.12 \mathrm{NaAlO}_{2} / 32 \mathrm{H}_{2} \mathrm{O}$. The silica monoliths are placed on the bottom of an autoclave $(250 \mathrm{~mL})$ with flat base and are impregnated with the basic alumina solution. The autoclave is placed in an oven at $40{ }^{\circ} \mathrm{C}$ for $20 \mathrm{~h}$. Monoliths are then recovered and put in a water bath $(1 \mathrm{~L})$ at room temperature. Water is changed every 30 min until reaching a neutral $\mathrm{pH}$ ( $\sim 4$ washings). Monoliths are then dried at $80{ }^{\circ} \mathrm{C}$ for $24 \mathrm{~h}$ and calcined at $550^{\circ} \mathrm{C}$ for $8 \mathrm{~h}$ under air.

Thirdly, silica-alumina monoliths were transformed into FAU-X monoliths. The pseudomorphic transformation of silica-alumina monoliths into FAU-X monoliths is performed at high $\mathrm{NaOH}$ concentration $[\mathrm{NaOH}]=2.19 \mathrm{M}$. In a beaker of $20 \mathrm{~mL}, 1.158 \mathrm{~g}$ $\mathrm{NaOH}$ is dissolved in $13.189 \mathrm{~g} \mathrm{H}_{2} \mathrm{O}$. The solution is stirred for $15 \mathrm{~min}$. The $\mathrm{pH}$ of the solution is 14.0. Two silica-alumina monoliths $(\mathrm{Al} / \mathrm{Si}=0.25)$ of $4 \mathrm{~cm}$ length, mass of $0.699 \mathrm{~g}$, are placed at the bottom of a flat stainless autoclave $(250 \mathrm{~mL})$. The monoliths are impregnated slowly with the $\mathrm{NaOH}$ solution. The autoclave is then placed in an oven at $40{ }^{\circ} \mathrm{C}$ for 4 days and then at $100{ }^{\circ} \mathrm{C}$ for $24 \mathrm{~h}$. The autoclave is then cooled in water bath. The excess of solution $(\mathrm{pH}$ 14.0) is removed with a Pasteur pipette. The monoliths are then placed in $1 \mathrm{~L}$ of water. Water is changed every hour until to reach a $\mathrm{pH}$ of 8 ( $\sim 4$ washings). The monoliths are then dried at $40{ }^{\circ} \mathrm{C}$ for $16 \mathrm{~h}$ and calcined with a heating rate of $0.5{ }^{\circ} \mathrm{C} / \mathrm{min}$ until $350{ }^{\circ} \mathrm{C}$ and maintained at $350{ }^{\circ} \mathrm{C}$ for $8 \mathrm{~h}$.

Another FAU-X monolith (Monolith FAU-X-3) has been prepared without the aging step at $40{ }^{\circ} \mathrm{C}$ for 4 days, by heating the reaction mixture directly at $100{ }^{\circ} \mathrm{C}$ for $24 \mathrm{~h}$. The skeleton of this monolith is build by an association of microcrystals (1-1.5 $\mu \mathrm{m})$.

\subsection{FAU-X particles synthesis}


The same protocol as for monoliths was applied to commercial mesoporous silica particles of $1 \mathrm{~mm}$ diameter (W432, Davisil) featuring a surface area of $\mathrm{S}_{\mathrm{BET}}=356 \mathrm{~m}^{2} / \mathrm{g}$, a mesopore diameter of $12.6 \mathrm{~nm}$, a mesopore volume of $1.14 \mathrm{~mL} / \mathrm{g}$. Silica particles $(600 \mathrm{mg})$ were put in an autoclave and impregnated with an alkaline solution prepared with $0.056 \mathrm{~g}$ $\mathrm{NaOH}, 5.742 \mathrm{~g} \mathrm{H}_{2} \mathrm{O}$ and $2.083 \mathrm{~g} \mathrm{NaAlO}_{2}$. The autoclave was maintained at $40{ }^{\circ} \mathrm{C}$ for $20 \mathrm{~h}$. The suspension was then filtered and washed with water until pH 7 (4 washings), dried at room temperature overnight and calcined at $550^{\circ} \mathrm{C}$ for $8 \mathrm{~h}\left(2^{\circ} \mathrm{C} / \mathrm{min}\right)$. The transformation of silica particles into silica-alumina particles corresponds to the molar ratios: $1 \mathrm{SiO}_{2} / 1.12$ $\mathrm{NaAlO}_{2} / 32 \mathrm{H}_{2} \mathrm{O} / 0.14 \mathrm{NaOH}$. Silica-alumina particles have a final molar ratio of $\mathrm{Al} / \mathrm{Si}=$ 0.22. These silica-alumina particles will be used to synthesize FAU-X particles named Particles FAU-X-1 featuring low aggregation of nanocrystals.

To increase the amount of aluminium in the particles a slight modification of the protocol was performed by using a larger amount of $\mathrm{NaAlO}_{2}\left(1 \mathrm{SiO}_{2} / 2.54 \mathrm{NaAlO}_{2} / 32 \mathrm{H}_{2} \mathrm{O}\right.$ / $0.14 \mathrm{NaOH}$ ) and a small amount of tetrapropylammonium gel, which synthesis is described elsewhere [19]. Silica-alumina particles have a final molar ratio $\mathrm{Al} / \mathrm{Si}=0.32$. These silicaalumina particles will be used to synthesize FAU-X particles named Particles FAU-X-2 featuring high aggregation of nanocrystals.

The same protocol of transformation of silica-alumina particles into FAU-X particles was used for the two kinds of silica-alumina particles. Silica-alumina particles ( $762 \mathrm{mg}$ ) were put in an autoclave with a basic solution prepared with $0.099 \mathrm{~g} \mathrm{NaOH}$ and $11.321 \mathrm{~g} \mathrm{H}_{2} \mathrm{O}$ and heated at $40{ }^{\circ} \mathrm{C}$ for 4 days and at $100{ }^{\circ} \mathrm{C}$ for $24 \mathrm{~h}$. The particles were washed until $\mathrm{pH} 8$, dried at $40{ }^{\circ} \mathrm{C}$ overnight and calcined at $350^{\circ} \mathrm{C}$ for $8 \mathrm{~h}\left(0.5^{\circ} \mathrm{C} / \mathrm{min}\right)$.

\subsection{Materials characterization}

X-Ray Diffraction (XRD) patterns of the monoliths were performed using a Bruker D8 Advance diffractometer with a Bragg-Brentano geometry and equipped with a Bruker Lynx Eye detector. XRD patterns were recorded in the range $4-50^{\circ}(2 \theta)$ to identify zeolite peaks. The angular step size was of $0.0197^{\circ}$ and the counting time of $0.2 \mathrm{~s}$ per step.

The textural properties of the materials were determined from the $\mathrm{N}_{2}$ adsorption/desorption isotherms at $77 \mathrm{~K}$ measured on a Micromeritics Tristar 3000 apparatus. The samples were previously outgassed in vacuum at $250{ }^{\circ} \mathrm{C}$ for $12 \mathrm{~h}$. Micropore volumes of FAU-X were determined at $\mathrm{p} / \mathrm{p}_{0}=0.1$ when all micropores are filled. 
Monoliths morphology was studied using a Hitachi S-4800 I FEG-SEM Scanning Electron Microscope at "Plateau Technique de l'IEM laboratoire du Pole Chimie Balard Montpellier".

Energy Dispersive Spectroscopy (EDS) chemical analyses (in atomic \%) were performed on a FEI Quanta 200F (15 kV) apparatus.

\subsection{Cs capture in pure and mineral water}

\subsubsection{Tests in batch with CsOAc in mineral water.}

To evaluate the kinetics of adsorption of the materials a solution of cesium acetate $[\mathrm{CsOAc}]=3.59 \mathrm{mmol} / \mathrm{L}$ has been prepared in mineral drinking water $(\mathrm{pH}=7.5)$ giving a $\mathrm{pH}$ of 7.9. This mineral drinking water (Evian, France) is commercially available and contains several cations: $\left[\mathrm{Ca}^{2+}\right]=2 \mathrm{mmol} / \mathrm{L},\left[\mathrm{Mg}^{2+}\right]=1 \mathrm{mmol} / \mathrm{L},\left[\mathrm{Na}^{+}\right]=0.2 \mathrm{mmol} / \mathrm{L},\left[\mathrm{K}^{+}\right]=0.02$ $\mathrm{mmol} / \mathrm{L}$. For batch experiments, FAU-X monoliths have been grinded in between 250 and $500 \mu \mathrm{m}$. FAU-X particles have been used without grinding.

Different tubes containing $20 \mathrm{mg}$ of adsorbents in $40 \mathrm{~mL}$ of CsOAc solution $(0.5 \mathrm{~g} / \mathrm{L})$ were stirred in a rotating stirrer at $60 \mathrm{rpm}$ (Fig. S1). Aliquots of supernatant were collected periodically using a syringe equipped with a $0.2 \mu \mathrm{m}$ filter in order to avoid artifact coming from solid particles. The amount of $\mathrm{Cs}^{+}$present in the supernatants was analyzed by atomic emission spectroscopy. After $24 \mathrm{~h}$ stirring, the tubes were centrifuged and the resulting powders were dried without washing to be analyzed by EDS.

\subsubsection{Tests in batch with $\mathrm{CsNO}_{3}$ in pure and mineral water.}

To evaluate the capacity of adsorption as a function of Cs concentration, similar tests as above were performed with cesium nitrate at different concentrations 0.50 and 0.74 $\mathrm{mmol} / \mathrm{L}$ in deionized water $(\mathrm{pH}=6.5)$ and mineral water $(\mathrm{pH}=7.5)$ with different amount of adsorbents 0.5 and $1 \mathrm{~g} / \mathrm{L}$.

\subsubsection{Tests in continuous flow with CsOAc in mineral water.}

The monolith FAU-X-2 of $0.5 \mathrm{~cm}$ diameter and $2.4 \mathrm{~cm}$ length $(\mathrm{m}=0.181 \mathrm{~g}$, volume $=$ $0.471 \mathrm{~cm}^{3}$, density $=0.60 \mathrm{~g} / \mathrm{cm}^{3}$ ) has been cladded with 2 Inox tubes with a heat shrinkable gain (DERAY PTFE 2 : 1, Castello France) at $350{ }^{\circ} \mathrm{C}$ for $5 \mathrm{~min}$ and connected to a HPLC pump through swageloks (Fig. S2). A solution of CsOAc of initial concentration $\mathrm{C}_{0}=0.5$ $\mathrm{mmol} / \mathrm{L}$ in mineral water was first flown through the monolith with a flow rate of 0.5 
$\mathrm{mL} / \mathrm{min}$, corresponding to a linear Darcy rate of $1.52 \mathrm{~m} / \mathrm{h}$. The Darcy rate is a lineic rate as the ratio of the flow rate $(\mathrm{mL} / \mathrm{min})$ and the surface area of the column (here the surface area of the monolith). The solution was collected in a beaker and sampled every $30 \mathrm{~min}$ for $10 \mathrm{~min}$ until $700 \mathrm{~min} . \mathrm{Cs}^{+}$content was analyzed by atomic emission spectroscopy.

The monolith was regenerated with a $\mathrm{NaCl}$ solution $2 \mathrm{~mol} / \mathrm{L}$ at $\mathrm{pH} 8(\mathrm{pH}$ adjustement was done by adding a small amount of sodium acetate $(0.1 \% \mathrm{v} / \mathrm{v}))$. The $\mathrm{NaCl}$ solution was flow through the monolith at a flow rate of $0.5 \mathrm{~mL} / \mathrm{min}$ for $10 \mathrm{~h}$ to recover the Na-FAU-X form. A second adsorption with CsOAc solution was performed with a flow rate of 0.5 $\mathrm{mL} / \mathrm{min}$ as for the first adsorption. A second regeneration was performed with the $\mathrm{NaCl}$ solution at a flow rate of $0.25 \mathrm{~mL} / \mathrm{min}$ for $87 \mathrm{~h}$. A third adsorption with CsOAc solution was performed with a flow rate of $0.5 \mathrm{~mL} / \mathrm{min}$ as for the first and second adsorptions. A third regeneration was performed with $\mathrm{NaCl}$ solution at a flow rate of $0.5 \mathrm{~mL} / \mathrm{min}$ for $12 \mathrm{~h}$. A forth adsorption with CsOAc solution was performed at higher flow rate of $1.0 \mathrm{~mL} / \mathrm{min}$ corresponding to $3.04 \mathrm{~m} / \mathrm{h}$.

\subsubsection{Analysis of $\mathrm{Cs}^{+}$solution by emission atomic spectroscopy.}

$\mathrm{Cs}^{+}$solutions have been analyzed by atomic emission spectroscopy with the band at $852.1 \mathrm{~nm}$ with a flame spectrometer Varian spectra 220. Calibration curves were performed with $\mathrm{Cs}^{+}$solutions $\left(\mathrm{CsOAc}\right.$ and $\left.\mathrm{CsNO}_{3}\right)$ of different concentrations from 20 to $100 \mathrm{ppm}$ $(\mathrm{mg} / \mathrm{L})$. Analyses of $\mathrm{Cs}^{+}$content in supernatants were done using the Beer-Lambert law.

\section{Results and discussion}

\subsection{Adsorbents characterization}

Recently, a new synthesis of FAU-X monoliths featuring homogeneous flow-through macropores (Fig. 1-3) ideal for continuous flow processes with high mass transfer has been disclosed [19]. FAU-X monoliths are obtained as cylinders of $0.5 \mathrm{~cm}$ diameter and $3 \mathrm{~cm}$ length. FAU-X monoliths present a skeleton build by an aggregation of nanocrystals, which are highly suitable to improve diffusion and access to the active sites of zeolites. The FAU-X nanocrystals inside the monoliths present two populations of different sizes: 100-200 nm and 400-900 nm (Fig. 1, Table 1). XRD patterns (Fig. 2) are characteristic of well-crystallized FAU-X zeolite, free of amorphous or extra crystalline phases. Such materials should allow increased adsorption capacities in comparison to zeolite monoliths or commercial zeolite particles shaped by using inorganic binders $(10-30 \quad \mathrm{wt} \%)$. The nitrogen 
adsorption/desorption isotherms of FAU-X monoliths are of type I characteristic of microporous materials with a micropore volume around $0.30 \mathrm{~mL} / \mathrm{g}$ (Fig. 3). At high pressure $\left(\mathrm{p} / \mathrm{p}_{0}>0.6\right)$, the isotherms show the presence of a secondary large porosity (pore diameter $>$ $10 \mathrm{~nm})$ due to the space in between the nanocrystals. This secondary porosity has been analyzed by mercury porosimetry and corresponds to pores usually in between 30 to $1000 \mathrm{~nm}$ centered at $300 \mathrm{~nm}$ amounting to a secondary pore volume of around $0.40 \mathrm{~mL} / \mathrm{g} \mathrm{[19].} \mathrm{The}$ macropore diameter is adjustable between 2 and $20 \mu \mathrm{m}$. The macropore volume stands around $1 \mathrm{~mL} / \mathrm{g}$. The density is around $0.56 \mathrm{~g} / \mathrm{cm}^{3}$. These FAU-X monoliths are obtained by a double pseudomorphic transformation of silica monoliths into silica-alumina monoliths $(0.25<\mathrm{Al} / \mathrm{Si}$ $<0.40)$ and then into FAU-X monoliths ( $\mathrm{Si} / \mathrm{Al} \sim 1.25)$ [19]. Two FAU-X monoliths built with nanocrystals with different macropore diameters of 2 and $20 \mu \mathrm{m}$, named Monolith-FAU-X-1 and 2, respectively, have been synthesized to evaluate their $\mathrm{Cs}^{+}$adsorption properties from aqueous solutions. Their textural characteristics are disclosed in Table 1.

The same protocol was successfully applied to the pseudomorphic transformation of silica particles of $1 \mathrm{~mm}$. Parent silica particles featuring mesopore diameters of $13 \mathrm{~nm}$, a specific surface area of $\mathrm{S}_{\mathrm{BET}}=356 \mathrm{~m}^{2} / \mathrm{g}$ and a mesopore volume of $1.14 \mathrm{~mL} / \mathrm{g}$ were transformed into silica-alumina particles (mesopore diameter $14 \mathrm{~nm}, \mathrm{~S}_{\mathrm{BET}}=170 \mathrm{~m} / \mathrm{g}$, mesopore volume of $1.67 \mathrm{~mL} / \mathrm{g}$ ). Then silica-alumina particles were transformed into FAU-X particles (Fig. 4) of the same size $(1 \mathrm{~mm})$ as the initial silica parent particles. Two kinds of FAU-X particles have been obtained depending on the $\mathrm{Al} / \mathrm{Si}$ ratio of the parent silica-alumina particles. For silica-alumina particles with $\mathrm{Al} / \mathrm{Si}=0.22$, the $\mathrm{FAU}-\mathrm{X}$ particles are built with nanocrystals of $100-200 \mathrm{~nm} / 400-500 \mathrm{~nm}$ with a low state of aggregation leading to pores $(100-400 \mathrm{~nm})$ in between the aggregates. This material is named "Particles FAU-X-1" (Fig. 4, Table 1). For parent silica-alumina particles with $\mathrm{Al} / \mathrm{Si}=0.32$, FAU-X particles are built with nanocrystals of 500-700 $\mathrm{nm}$ with a high state of aggregation, this material is named "Particles FAU-X-2" (Fig. 4, Table 1). The increase in nanocrystals size by increasing Al/Si ratio in the silica-alumina particles is in agreement with observations in literature for FAU-X [22]. Both kinds of FAU-X particles feature the XRD pattern of well-crystallized FAU-X (Fig. S3) and nitrogen isotherms similar to FAU-X monoliths with micropore volume around $0.30 \mathrm{~mL} / \mathrm{g}$ (Fig. S4, Table 1).

The Cu-HCF@ $\mathrm{SiO}_{2}$ benchmark material used in literature $[17,18]$ has a general chemical formula of $\mathrm{K}_{1.16} \mathrm{Cu}_{1.42} \mathrm{Fe}(\mathrm{CN})_{6}, 59 \mathrm{SiO}_{2}$ corresponding to a theoretical cationexchange capacity of $0.29 \mathrm{meq} / \mathrm{g}$. Its textural characteristics are the following: mesopore volume of $0.57 \mathrm{~mL} / \mathrm{g}$, mesopores diameter opening of $9 \mathrm{~nm}$, specific surface area of $283 \mathrm{~m}^{2} / \mathrm{g}$ 
and nanocrystals size of $15 \mathrm{~nm}$ [17]. The density of $\mathrm{Cu}-\mathrm{HCF} @ \mathrm{SiO}_{2}$ is around $0.45 \mathrm{~g} / \mathrm{cm}^{3}$. This adsorbent has revealed high performance in continuous flow for $\mathrm{Cs}^{+}$sequestering from $\mathrm{Cs}^{+}$in solution in mineral water containing competitive cations $\left(\mathrm{K}^{+}, \mathrm{Na}^{+}, \mathrm{Mg}^{2+}, \mathrm{Ca}^{2+}\right)[18]$.

\subsection{Cesium adsorption in FAU-X monoliths and particles in batch}

\subsubsection{Cesium capture from $\mathrm{CsOAc}$ solution in mineral water in batch}

FAU-X is known to have the best stability at $\mathrm{pH}$ around 8 . The mineral drinking water $(\mathrm{pH}$ 7.5) used in this study is the same as the one used in literature to evaluate the adsorption capacity of the benchmark material $\mathrm{Cu}-\mathrm{HCF} @ \mathrm{SiO}_{2}$ in batch [17] and in flow [18]. This mineral water has been chosen as it is considered to be the more constant one in composition among mineral waters. Cesium acetate ( $\mathrm{CsOAc})$ was chosen as salt to increase the $\mathrm{pH}$ the solution close to 8 . For a solution of $\left[\mathrm{Cs}^{+}\right]=3.59 \mathrm{mmol} / \mathrm{L}$ with $0.5 \mathrm{~g} / \mathrm{L}$ of FAU-X, the final $\mathrm{pH}$ was 7.9. This corresponds to an amount of $\mathrm{Cs}^{+}$per mass of adsorbent of $7.18 \mathrm{meq} / \mathrm{g}$ for a theoretical cation-exchange capacity for FAU-X of $3.92 \mathrm{meq} / \mathrm{g}$ or $1.93 \mathrm{meq} / \mathrm{g}$ if more than $40 \%$ of $\mathrm{Na}^{+}$are exchanged. The mineral water contains different cations $\left[\mathrm{Ca}^{2+}\right]=2 \mathrm{mmol} / \mathrm{L}$, $\left[\mathrm{Mg}^{2+}\right]=1 \mathrm{mmol} / \mathrm{L},\left[\mathrm{Na}^{+}\right]=0.2 \mathrm{mmol} / \mathrm{L},\left[\mathrm{K}^{+}\right]=0.02 \mathrm{mmol} / \mathrm{L}$, which are competing with $\mathrm{Cs}^{+}$ adsorption. This amount of competing cations corresponds to an amount for each cations per mass of adsorbent of 8, 4, 0.4, $0.04 \mathrm{meq} / \mathrm{g}$, respectively. For batch experiments, FAU-X monoliths have been grinded into particles of $250-500 \mu \mathrm{m}$ to get similar sizes as benchmark $\mathrm{Cu}-\mathrm{HCF} @ \mathrm{SiO}_{2}$.

FAU-X monoliths show very fast kinetics of cation-exchange, as the maximum $\mathrm{Cs}^{+}$ adsorption capacity is reached in less than $2 \mathrm{~min}$ (Fig. 5). This property is of great importance for continuous flow processes. Indeed, the higher is the adsorption rate, the higher will be the dynamic adsorption rate. This high rate results from the porosity of the monoliths allowing fast diffusion of $\mathrm{Cs}^{+}$inside the zeolite. FAU-X monolith (Monolith FAU-X-1) featuring a $\mathrm{Si} / \mathrm{Al}=1.28$ (Table 2) shows a maximum exchange capacity of $1.75 \mathrm{meq} / \mathrm{g}$ (Fig. 5). This result is in accordance with theoretical CEC of $\mathrm{Cs}^{+}$for FAU-X $1.66<\mathrm{CEC}<1.93 \mathrm{meq} / \mathrm{g}$ (for $\mathrm{Si} / \mathrm{Al}$ from 1.5 to 1.25 , respectively) with a cation-exchange capacity higher than $40 \%$ [10]. FAU-X monolith built of microcrystals (Monolith FAU-X-3, Si/Al $=1.46$ ) shows a similar fast cation exchange in less than $2 \mathrm{~min}$, but a lower maximum exchange capacity of $1.0 \mathrm{meq} / \mathrm{g}$ (not shown). No increase in adsorption capacities was observed during $24 \mathrm{~h}$.

FAU-X particles $(1 \mathrm{~mm}, \mathrm{Si} / \mathrm{Al}=1.4-1.5)$ formed by aggregation of nanocrystals (Table 2) lead to slower kinetics with a maximum $\mathrm{Cs}^{+}$adsorption capacity $(1.0 \mathrm{meq} / \mathrm{g})$ 
reached in 30 - $60 \mathrm{~min}$ (Fig. 5). No changes in adsorption capacity were observed after $24 \mathrm{~h}$ in $\mathrm{Cs}^{+}$solution. FAU-X monoliths (nano- or microcrystals) demonstrate a much faster cationexchange than FAU-X particles. This is attributed to the homogeneous network of large macropores in the monoliths, which enhances the transport to the active site of the zeolite. This highlights the importance of a hierarchical porosity in adsorbents for fast ion diffusion.

After $24 \mathrm{~h}$ in $\mathrm{Cs}^{+}$solution, the tubes containing the adsorbents were centrifuged, the supernatant solutions removed and the samples dried (without washing). After centrifugation the FAU-X particles featuring low aggregation of nanocrystals (Particles FAU-X-1) have been destroyed as a fine powder. Chemical analyses were performed on the dried solids (Table 2). The results show that most of $\mathrm{Na}^{+}$(92-93\%) has been exchanged in FAU-X monoliths and FAU-X particles and that a high amount of $\mathrm{Ca}^{2+}$ has been adsorbed. The amount of $\mathrm{Cs}^{+}\left(1.62 \mathrm{meq} / \mathrm{g}_{\text {final }}\right)$ in FAU-X monolith featuring nanocrystals (Monolith-FAU-X1) is in agreement with the result obtained by measuring the remaining $\mathrm{Cs}^{+}$in solution $(1.75$ meq $\left./ \mathrm{g}_{\text {initial }}\right)$. For both FAU-X particles and FAU-X monolith featuring microcrystals (Monolith-FAU-X-3) the amount of $\mathrm{Cs}^{+}$found in the solid $(\sim 1.85 \mathrm{meq} / \mathrm{g})$ is significantly higher than the one determined from the remaining $\mathrm{Cs}^{+}$in solution $(1.0 \mathrm{meq} / \mathrm{g})$. This can be the result of some precipitation/occlusion of CsOAc salts on the solid during drying, as no washing was performed after centrifugation.

From the composition of the solids after drying (Table 2), the amount of the different cations present in the solid has been calculated and expressed as meq/g. The amount of cations present initially in solution corresponds to $\mathrm{Cs}^{+} 7.2 \mathrm{meq} / \mathrm{g}, \mathrm{Ca}^{2+} 8 \mathrm{meq} / \mathrm{g}^{2} \mathrm{Mg}^{2+} 4$ $\mathrm{meq} / \mathrm{g}, \mathrm{Na}^{+} 0.4 \mathrm{meq} / \mathrm{g}, \mathrm{K}^{+} 0.04 \mathrm{meq} / \mathrm{g}$. For FAU-X monolith featuring nanocrystals, the amount of the different cations after $\mathrm{Cs}^{+}$adsorption corresponds to $\mathrm{Cs}^{+} 1.6 \mathrm{meq} / \mathrm{g}, \mathrm{Ca}^{2+} 6.4$ $\mathrm{meq} / \mathrm{g}, \mathrm{Mg}^{2+} 0.7 \mathrm{meq} / \mathrm{g}, \mathrm{Na}^{+} 0.7 \mathrm{meq} / \mathrm{g}, \mathrm{K}^{+} 0.02 \mathrm{meq} / \mathrm{g}$. This gives a total of $9.4 \mathrm{meq} / \mathrm{g}$ of cations in FAU-X monolith higher than the maximum theoretical CEC value (4.83 meq/g). As presumably no $\mathrm{CsOAc}$ has precipitated on this adsorbent, one explanation is that $\mathrm{Ca}(\mathrm{OAc})_{2}$ salt has precipitated on the solid. Indeed, the solubility of $\mathrm{Ca}(\mathrm{OAc})_{2}(0.4 \mathrm{~kg} / \mathrm{L})$ is lower than the one of CsOAc $(9 \mathrm{~kg} / \mathrm{L})$. To reach the theoretical maximum CEC of FAU-X $(4.83 \mathrm{meq} / \mathrm{g})$, an amount equivalent to $4.6 \mathrm{meq} / \mathrm{g}$ of $\mathrm{Ca}^{2+}$ should have precipitated on the solid and 1.8 meq/g Ca ${ }^{2+}$ should be at exchange positions. For the other FAU-X adsorbents, with a less porous structure, both precipitations of $\mathrm{CsOAc}$ and $\mathrm{Ca}(\mathrm{OAc})_{2}$ should occur.

\subsubsection{Cesium capture from $\mathrm{CsNO}_{3}$ solution in mineral water in batch}


Batch experiments have been performed with solution of $\mathrm{CsNO}_{3}$ in mineral water at different concentrations 0.50 and $0.74 \mathrm{mmol} / \mathrm{g}$ and 2 loadings of adsorbents 0.5 and $1 \mathrm{~g} / \mathrm{L}$, which correspond to an amount per g of adsorbent of $0.50,0.74,1.0,1.48 \mathrm{meq} / \mathrm{g}$. The $\mathrm{CsNO}_{3}$ solution in mineral water has a $\mathrm{pH}$ of 7.9. The suspensions were stirred for $1 \mathrm{~h}$ before analyzing the $\mathrm{Cs}^{+}$content of the filtered supernatants.

$\mathrm{Cs}^{+}$adsorption capacity of FAU-X monoliths and particles increase from 0.35 to 0.70 meq/g with the increase of $\mathrm{Cs}^{+}$in solution corresponding to an amount per $\mathrm{g}$ of adsorbents of 0.50 to $1.48 \mathrm{meq} / \mathrm{g}$ (Fig. S5). Adsorption isotherms have been drawn considering the remaining $\mathrm{Cs}^{+}$in equilibrium with the solution after adsorption (Fig. 6). The equilibrium concentration expressed in meq/g (Fig. 6) will be similar to equilibrium concentration in $\mathrm{mmol} / \mathrm{L}$ for adsorbents loadings of $1 \mathrm{~g} / \mathrm{L}$. Two main informations are contained in these curves: the slope at low $\mathrm{Cs}^{+}$concentrations remaining in solution, which is linked to the selectivity of the adsorbents, a higher slope corresponds to higher selectivity towards $\mathrm{Cs}^{+}$, and the value of the plateau from isotherms curves corresponding to the maximum cationexchange capacity. According to these data, the experimental adsorption capacity of FAU-X monoliths (for an initial amount of $\mathrm{Cs}^{+}$in solution of $1.48 \mathrm{meq} / \mathrm{g}$ ) is around $0.70 \mathrm{meq} / \mathrm{g}$ as for FAU-X particles featuring low nanocrystals aggregation and $0.65 \mathrm{meq} / \mathrm{g}$ for FAU-X particles featuring high nanocrystals aggregation.

To calculate the maximum adsorption capacities, the adsorption isotherms have been fitted with a Langmuir isotherm model. The Langmuir isotherm is most widely used for the adsorption of molecules or ions from a liquid solution [23]. The model is based on several basic assumptions: (i) the adsorption takes place at specific homogeneous sites within adsorbent; (ii) a molecule or an ion occupies one site; (iii) the adsorbent has a finite capacity for the adsorbate (at equilibrium, a saturation point is reached where no further adsorption can occur); (iv) all sites are identical and energetically equivalent (the adsorbent is structurally homogeneous).

The equation of Langmuir for the sorption of a single component, namely $\mathrm{Cs}^{+}$, is represented as follows [23]:

$$
Q=\frac{Q_{m} K_{L} C_{e}}{1+K_{L} C_{e}}
$$

where Q (meq/g) is the adsorbed amount of $\mathrm{Cs}^{+}$in the solid at equilibrium $\mathrm{Cs}^{+}$concentration in the solution $\mathrm{C}_{\mathrm{e}}(\mathrm{mmol} / \mathrm{L}), \mathrm{Q}_{\mathrm{m}}(\mathrm{mmol} / \mathrm{g})$ the maximum adsorption capacity and $\mathrm{K}_{\mathrm{L}}$ 
$(\mathrm{L} / \mathrm{mmol})$ is a constant related to the equilibrium constant of adsorption and to the energy of adsorption $[23,24]$. The Langmuir isotherm parameters are evaluated through linearization of the Langmuir equation:

$$
\frac{C_{e}}{Q}=\frac{1}{K_{L} Q_{m}}+\frac{1}{Q_{m}} C_{e}
$$

Hence by plotting $C_{e} / Q$ against $C_{e}$ it is possible to obtain the value of $Q_{m}$ from the slope and $\mathrm{K}_{\mathrm{L}}$ from the intercept.

The $\mathrm{Cs}^{+}$adsorption isotherms in mineral water of FAU-X monoliths and particles follow the Langmuir isotherm model with a good correlation coefficient $\left(\mathrm{R}^{2}>0.99\right)$ (Table 3). The values of $\mathrm{Q}_{\mathrm{m}}$ and $\mathrm{K}_{\mathrm{L}}$ for the Langmuir equation are reported in Table 3. The maximum adsorption capacity for FAU-X monoliths is equivalent to FAU-X particles featuring low nanocrystals aggregation with $\mathrm{Q}_{\mathrm{m}}=1.0 \mathrm{meq} / \mathrm{g}$, whereas the maximum adsorption capacity is slightly lower for FAU-X particles featuring high nanocrystals aggregation with a maximum capacity of $0.8 \mathrm{meq} / \mathrm{g}$. The $\mathrm{K}_{\mathrm{L}}$ constants are around 3-4 L/meq or $\mathrm{L} / \mathrm{mmol}$, which is comparable to the $\mathrm{K}_{\mathrm{L}}$ constant obtained for $\mathrm{Cs}^{+}$adsorption in seawater with nanocrystals of mordenite $\left(\mathrm{K}_{\mathrm{L}}=2.6 \mathrm{~L} / \mathrm{mmol}\right.$ with $\left.\mathrm{Q}_{\mathrm{m}}=0.28 \mathrm{meq} / \mathrm{g}\right)$ [25].

FAU-X monolith (Monolith FAU-X-1) featuring nanocrystals in the skeleton shows a lower maximum adsorption capacity $(1.0 \mathrm{meq} / \mathrm{g})$ with $\mathrm{CsNO}_{3}$ solution in comparison to CsOAc solution $(1.75 \mathrm{meq} / \mathrm{g})$, whereas similar maximum adsorption capacities $(1.0 \mathrm{meq} / \mathrm{g})$ were obtained for Monolith FAU-X-2 featuring microcrystals and FAU-X particles (Tables 2, 3). A hypothesis would be that some $\mathrm{Ca}(\mathrm{OAc})_{2}$ precipitated by confinement in the secondary porosity of Monolith FAU-X-1 leading to less $\mathrm{Ca}^{2+}$ competing with $\mathrm{Cs}^{+}$to occupy the exchange sites of the zeolite, enabling a higher adsorption capacity of $\mathrm{Cs}^{+}$with $\mathrm{CsOAc}$ solution than with $\mathrm{CsNO}_{3}$ solution. For $\mathrm{Cs}^{+}$adsorption under flow conditions performed with CsOAc solution (see below) no confinement will be possible. The adsorption isotherms obtained with $\mathrm{CsNO}_{3}$ solution will be used to evaluate the adsorption capacity of FAU-X monoliths in contact with $\mathrm{Cs}^{+}$solutions. The adsorption isotherm shows that for an equilibrium concentration of $\left[\mathrm{Cs}^{+}\right]=0.5 \mathrm{mmol} / \mathrm{L}$ ( or $0.5 \mathrm{meq} / \mathrm{g}$ ), the adsorption capacity of FAU-X monoliths will be $0.60 \mathrm{meq} / \mathrm{g}$ (Fig. 6). This will correspond to an adsorption capacity per volume of material of $0.36 \mathrm{meq} / \mathrm{cm}^{3}$. In literature $[17,18]$ for the same $\mathrm{Cs}^{+}$equilibrium concentration, the adsorption capacity of $\mathrm{Cu}-\mathrm{HCF} @ \mathrm{SiO}_{2}$ was $0.20 \mathrm{meq} / \mathrm{g}$, corresponding to an adsorption capacity per volume of material of $0.10 \mathrm{meq} / \mathrm{cm}^{3}$. 
In batch in mineral water, FAU-X monoliths adsorb 3 times more $\mathrm{Cs}^{+}$in comparison to benchmark $\mathrm{Cu}-\mathrm{HCF} @ \mathrm{SiO}_{2}$ for a same volume of adsorbent.

\subsubsection{Cesium capture from $\mathrm{CsNO}_{3}$ solution in deionized water in batch}

Adsorption experiments were also conducted with deionized water without competing cations with $\mathrm{CsNO}_{3}$ solutions concentrations identical as previously: $\left[\mathrm{Cs}^{+}\right]=0.50$ and 0.74 $\mathrm{mmol} / \mathrm{g}$ and adsorbents concentrations equal to 0.5 and $1 \mathrm{~g} / \mathrm{L}$ (Fig. S6).

For FAU-X monoliths and particles, no plateau of $\mathrm{Cs}^{+}$adsorption capacity was reached with deionized water for the $\mathrm{Cs}^{+}$concentrations used in this section (Fig. 7). $\mathrm{Cs}^{+}$adsorption capacities of FAU-X monoliths and particles in deionized water are higher than $1.30 \mathrm{meq} / \mathrm{g}$ (Fig. 7, S6). The comparison of adsorption capacity in deionized water (Fig.7) and in mineral water (Fig. 6) clearly shows the lower affinity of $\mathrm{Cs}^{+}$for FAU-X when competing cations as $\mathrm{Ca}^{2+}$ are present.

\subsection{Cesium adsorption in FAU-X monoliths in continuous flow}

$\mathrm{Cs}^{+}$adsorption under continuous flow was performed in similar conditions as the optimal ones described for $\mathrm{Cu}-\mathrm{HCF} @ \mathrm{SiO}_{2}$ in literature [18]: mineral water, $\left[\mathrm{Cs}^{+}\right]=0.5$ $\mathrm{mmol} / \mathrm{L}$, a column ratio length/diameter $\mathrm{L} / \mathrm{D}=5$, a flow rate corresponding to a Darcy rate around $2 \mathrm{~m} / \mathrm{h}$. In such conditions, $\mathrm{Cu}-\mathrm{HCF} @ \mathrm{SiO}_{2}$ gave a steep breakthrough curve with an efficient adsorption capacity of $230 \mathrm{~mL}$ of solution efficiently treated (all $\mathrm{Cs}^{+}$being captured) per unit volume of column $\left(1 \mathrm{~cm}^{3}\right)$, so 230 Bed Volume (BV) corresponding to $0.14 \mathrm{meq} / \mathrm{g}$. An adsorption capacity at half-breakthrough curve of $250 \mathrm{BV}(0.15 \mathrm{meq} / \mathrm{g})$ has been obtained with a maximum dynamic capacity of $300 \mathrm{BV}(0.18 \mathrm{meq} / \mathrm{g})$. The diffusion rate in $\mathrm{Cu}-$ $\mathrm{HCF} @ \mathrm{SiO}_{2}$ is large enough to achieve the maximum efficiency of the column. The dynamic capacity of this material represents $100 \%$ of its useful capacity, all exchangeable sites of the column are accessible [18].

FAU-X monoliths featuring nanocrystals have been chosen among all FAU-X adsorbents, as they give faster kinetics of adsorption together with the highest adsorption capacity in batch (Fig. 5). A first FAU-X monolith (similar to Monolith FAU-X-1) featuring 3 $\mu \mathrm{m}$ macropore diameter has been tested with $\mathrm{C}_{0}=[\mathrm{CsOAc}]=0.5 \mathrm{mmol} / \mathrm{L}$ at a flow rate of 0.5 $\mathrm{mL} / \mathrm{min}$ (corresponding to a Darcy rate of $1.52 \mathrm{~m} / \mathrm{h}$ ). Under the flow conditions, the pressure increased in the column and no analysis could be performed. A second FAU-X monolith (Monolith FAU-X-2, $0.5 \mathrm{~cm}$ diameter x $2.4 \mathrm{~cm}$ length, $181 \mathrm{mg}$, density $0.60 \mathrm{~g} / \mathrm{cm}^{3}$ ) with 
larger macropores of $20 \mu \mathrm{m}$ diameter (Fig. 1-3, Table 1) has been synthesized and used in continuous flow.

Breakthrough curves were obtained by plotting the concentration of $\mathrm{Cs}^{+}$at the exit of the monolith (C) as a function of time (Fig. S7) or volume throughput (Fig. 8). Breakthrough curves are usually expressed in terms of normalized concentration defined as the ratio of effluent ion concentration to its inlet concentration $\mathrm{C} / \mathrm{C}_{0}$ as a function of effluent volume for a given bed volume (Fig. 8). The shape of the breakthrough curve and the breakthrough volume (or time) are the most important factors for determining the dynamics and the practical aptitude of the flow process. The shape of a breakthrough curve as a function of volume (or time) depends on many parameters such as the bed volume, the ratio bed diameter/bed height (which should be superior to 5, as demonstrated for $\mathrm{Cu}-\mathrm{HCF} @ \mathrm{SiO}_{2}$ [18]), the flow rate and the feed concentration $\mathrm{C}_{0}$. An ideal breakthrough curve would show an instantaneous jump in the effluent concentration from zero to the value of the feed concentration when the column capacity is reached. In case of a highly selective adsorbent, the adsorption zone is linear, perpendicular to the bed and in this ideal case the height of this front depends only on the initial concentration of the effluent and on the Darcy rate. A Darcy rate higher than $1 \mathrm{~m} / \mathrm{h}$ is considered necessary for a representative experiment able to be scaled up at pilot and industrial scale.

First the $\mathrm{Cs}^{+}$solution has been flown through the FAU-X monolith at a flow rate of $0.5 \mathrm{~mL} / \mathrm{min}(1.52 \mathrm{~m} / \mathrm{h})$ for $24 \mathrm{~h}$ to scale the experiment. The FAU-X monolith was regenerated with $[\mathrm{NaCl}]=2 \mathrm{~mol} / \mathrm{L}$ to recover the $\mathrm{Na}-\mathrm{FAU}-\mathrm{X}$ form. This $\mathrm{NaCl}$ concentration has been chosen as in a previous study concerning the capture of $\mathrm{Sr}^{2+}$ with LTA zeolites, we have noticed that the capacity of adsorption of zeolites decreases with the increase of $\mathrm{Na}^{+}$ present in the solution and that no adsorption occurs for $\left[\mathrm{Na}^{+}\right]=1.6 \mathrm{~mol} / \mathrm{L}$ (Fig. S8). A second run of $\mathrm{Cs}^{+}$adsorption was conducted at a flow rate of $0.5 \mathrm{~mL} / \mathrm{min}(1.52 \mathrm{~m} / \mathrm{h})$ and gave a vertical breakthrough curve (Fig. 8, Fig. S7) with an efficient adsorption capacity delay of $180 \mathrm{~min}$ corresponding to $191 \mathrm{BV}$ and $0.25 \mathrm{meq} / \mathrm{g}$. The capacity at half-breakthrough curve was $255 \mathrm{BV}(0.33 \mathrm{meq} / \mathrm{g})$. The FAU-X monolith has been regenerated and a third $\mathrm{Cs}^{+}$ adsorption has been performed at a flow rate of $0.5 \mathrm{~mL} / \mathrm{min}(1.52 \mathrm{~m} / \mathrm{h})$ giving the same results (Fig. 8, Table 4). The FAU-X monolith has been regenerated again and a forth $\mathrm{Cs}^{+}$ adsorption has been performed at a flow rate of $1 \mathrm{~mL} / \mathrm{min}(3.04 \mathrm{~m} / \mathrm{h})$ giving the same breakthrough curve (Fig. 8, Table 4). The shapes of the breakthrough curves of FAU-X monolith build of nanocrystals are steep revealing the high diffusion of $\mathrm{Cs}^{+}$to the active sites of the zeolite due to the hierarchical nature of the porosity of the monolith, as it was observed 
for LTA monoliths build of nanocrystals for $\mathrm{Sr}^{2+}$ capture [2]. Rates of cationic exchange have been calculated using the Thomas model [26,27] as previously done for $\mathrm{Sr}^{2+}$ adsorption in flow with LTA monoliths [2]. The Thomas model assumes a Langmuir isotherm with a pseudo-second order expression in order to calculate the residual adsorption capacity. The model ignores dispersive effects such as axial dispersion or dispersive mass transfer. The Thomas model is following the equation:

$$
\frac{C_{0}}{C}-1=\exp \left(\frac{K_{t h} Q_{b e d} m}{F}-K_{t h} C_{0} t\right)
$$

or for linearization:

$$
\ln \left(\frac{C_{0}}{C}-1\right)=\frac{K_{t h} Q_{b e d} m}{F}-K_{t h} C_{0} t
$$

where $\mathrm{C}_{0}(\mathrm{mg} / \mathrm{L})$ is the initial $\mathrm{Cs}^{+}$concentration (at the entrance of the monolith), $\mathrm{C}(\mathrm{mg} / \mathrm{L})$ is the concentration of $\mathrm{Cs}^{+}$at time $\mathrm{t}(\mathrm{min})$ at the exit of the monolith, $\mathrm{K}_{\mathrm{th}}(\mathrm{L} / \mathrm{mg} / \mathrm{min})$ is the adsorption rate constant, $\mathrm{m}(\mathrm{mg})$ is the mass of the monolith, $\mathrm{F}(\mathrm{mL} / \mathrm{min})$ is the flow rate and $\mathrm{Q}_{\text {bed }}(\mathrm{mg} / \mathrm{g})$ is the maximum capacity of adsorption of the monolithic bed under dynamic conditions.

The $\mathrm{K}_{\text {th }}$ and $\mathrm{Q}_{\text {bed }}$ values (Table 4) were calculated from the slopes and the intercepts of the linear plots of $\ln \left(\mathrm{C}_{0} / \mathrm{C}-1\right)$ against $\mathrm{t}$ (Fig. S7). From the regression coefficient $\left(\mathrm{R}^{2}>0.989\right)$, it can be concluded that the experimental data fitted well with Thomas model. An adsorption rate constant $\mathrm{K}_{\text {th }}=1.60-1.90 \mathrm{~mL} / \mathrm{mg} / \mathrm{min}$ and a bed capacity of $Q_{\text {bed }}=0.33-0.37 \mathrm{meq} / \mathrm{g}$ were found. To know if the entire monolith has been used for the cation-exchange and if all exchangeable sites of the monolith are accessible, the dynamic capacity $(0.37 \mathrm{meq} / \mathrm{g})$ has to be compared with the "useful" capacity (or static capacity) corresponding to the experimental capacity in batch with an equilibrium $\mathrm{Cs}^{+}$concentration $(0.5 \mathrm{mmol} / \mathrm{L}$ or $0.5 \mathrm{meq} / \mathrm{g}$ in Fig. 6) equal to the feed concentration. The useful capacity of FAU-X monolith was $0.60 \mathrm{meq} / \mathrm{g}$, which is higher than the dynamic capacity $(0.37 \mathrm{meq} / \mathrm{g})$ measured at 1.5 and $3 \mathrm{~m} / \mathrm{h}$, meaning that some exchangeable sites of FAU-X are not used under flow experiments. The dynamic capacity of FAU-X monoliths at the end of the step of the breakthrough curve represents $62 \%$ of its useful capacity. 
The efficient $\mathrm{Cs}^{+}$adsorption capacity of FAU-X monoliths build of nanocrystals is 224 BV $(0.29 \mathrm{meq} / \mathrm{g})$, the half-breakthrough adsorption capacity $260 \mathrm{BV}(0.34 \mathrm{meq} / \mathrm{g})$ and the maximum dynamic adsorption capacity $296 \mathrm{BV}(0.38 \mathrm{meq} / \mathrm{g})$ for a solution of $\mathrm{Cs}^{+}$of 0.5 $\mathrm{mmol} / \mathrm{L}$ in mineral water (with competiting cations). Under similar conditions, the efficient $\mathrm{Cs}^{+}$adsorption capacity of $\mathrm{Cu}-\mathrm{HCF} @ \mathrm{SiO}_{2}$ benchmark material column was $230 \mathrm{BV}(0.14$ meq/g), the half-breakthrough adsorption capacity $250 \mathrm{BV}(0.15 \mathrm{meq} / \mathrm{g})$ and the maximum dynamic adsorption capacity $300 \mathrm{BV}(0.18 \mathrm{meq} / \mathrm{g})$ [18]. Whereas in batch the adsorption capacity of FAU-X monolith was 3 times higher than $\mathrm{Cu}-\mathrm{HCF} @ \mathrm{SiO}_{2}$, in continuous flow the dynamic adsorption capacity of FAU-X monolith is equivalent to those of $\mathrm{Cu}-\mathrm{HCF} @ \mathrm{SiO}_{2}$ (Fig. 8).

In literature, it was shown that higher kinetics of cation exchange were observed for higher mesopore volumes in mesoporous LTA [4]. For Cu-HCF@ $\mathrm{SiO}_{2}$, the mesopore volume is $0.57 \mathrm{~mL} / \mathrm{g}$ [17] corresponding to a mesopore volume per unit of volume of $0.26 \mathrm{~mL} / \mathrm{cm}^{3}$. For FAU-X monoliths the secondary porosity in between nanocrystals is $0.38 \mathrm{~mL} / \mathrm{g}$ corresponding to $0.23 \mathrm{~mL} / \mathrm{cm}^{3}$. The mesopore and secondary pore volumes to access to the nanocrystals of either $\mathrm{Cu}-\mathrm{HCF}$ nanoparticles or FAU-X nanocrystals are practically identical per unit volume. These pore volumes are responsible for fast ion transport to the active site and cannot be responsible for the lower dynamic capacity of FAU-X monoliths in comparison to its usefull capacity (in batch). The explanation of the difference is coming from the size of the nanocrystals. In the case of $\mathrm{Cu}-\mathrm{HCF}$ the nanoparticle size is around $15 \mathrm{~nm}$ and all the exchange sites are available under dynamic adsorption, whereas for FAU-X monoliths, two populations of nanocrystals size have been obtained: 100/200 nm and 800/900 nm (MonolithFAU-X-2, Table 2). It can be anticipated that only the smallest nanocrystals 100/200 nm are fully accessible for the dynamic cation exchange as well as the exterior corona of the larger nanocrystals.

\section{Conclusion}

Binderless FAU-X monoliths and particles $(1 \mathrm{~mm})$ have been synthesized by a double pseudomorphic transformation starting from silica mesoporous/macroporous monoliths with adjustable macropore diameters $(2<\mathrm{D}<20 \mu \mathrm{m})$ and mesoporous silica particles $(1 \mathrm{~mm})$, respectively. The parent silica materials were first transformed into silica-alumina materials, which were then transformed into FAU-X monoliths and particles build by an aggregation of nanocrystals giving rise to intercrystalline porosity beneficial for fast diffusion. FAU-X 
monoliths and particles have been used to trap cesium ions contained in mineral drinking water in the presence of competing cations as $\mathrm{Ca}^{2+}, \mathrm{Mg}^{2+}, \mathrm{K}^{+}, \mathrm{Na}^{+}$. Their performance as adsorbents for the decontamination of Cs-containing effluents have been compared to those of a benchmark adsorbent Sorbmatech ${ }^{\circledR}\left(\mathrm{Cu}-\mathrm{HCF} @ \mathrm{SiO}_{2}\right)$ based on copper hexaferrocyanate nanoparticles immobilized into mesoporous silica particles.

In batch FAU-X monoliths feature fast kinetic of adsorption (in less than $2 \mathrm{~min}$ ) as $\mathrm{Cu}-\mathrm{HCF} @ \mathrm{SiO}_{2}$ and higher rate of adsorption in comparison to FAU-X particles highlighting the importance of a homogeneous large macropore network for high fluid dynamics in the design of adsorbents. FAU-X monoliths possess an adsorption capacity 3 times higher than benchmark $\mathrm{Cu}-\mathrm{HCF} @ \mathrm{SiO}_{2}$ for equilibrium $\mathrm{Cs}^{+}$concentration of $0.5 \mathrm{mmol} / \mathrm{L}$ with capacities of 0.6 and 0.2 meq/g for FAU-X monolith and Cu-HCF@ $\mathrm{SiO}_{2}$, respectively.

The dynamic $\mathrm{Cs}^{+}$adsorption efficiency of FAU-X monoliths (macropore diameter of $20 \mu \mathrm{m})$ is equivalent to that of $\mathrm{Cu}-\mathrm{HCF} @ \mathrm{SiO}_{2}$ for the decontamination of Cs effluents in mineral water with a $\mathrm{Cs}^{+}$concentration of $0.5 \mathrm{mmol} / \mathrm{L}$ and Darcy rates of $1.5-3 \mathrm{~m} / \mathrm{h}$. FAU-X monoliths show ideal steep breakthrough curves with an efficient adsorption capacity of 224 Bed Volume (corresponding to $0.29 \mathrm{meq} / \mathrm{g}$ ) and a total dynamic capacity of 296 Bed Volume $(0.38 \mathrm{meq} / \mathrm{g})$. This dynamic adsorption capacity corresponds to $62 \%$ of its usefull capacity (obtained in batch), and could be probably increased by decreasing further the size of the nanocrystals of the monolith skeleton. FAU-X monoliths could represent an alternative to existing sorbents easier to handle than powders or particles. Moreover the possibility to regenerate, and reuse, the $\mathrm{FAU}-\mathrm{X}$ monoliths with $\mathrm{NaCl}$ solutions is also attractive for applications aimed at recovering the trapped cations.

This study shows that FAU-X monoliths built with nanocrystals featuring hierarchical trimodal porosity exhibit excellent dynamic properties and are excellent candidates for continuous flow applications for process intensification using classical FAU-X particles.

\section{ACKNOWLEDGMENTS}

This research was funded by the ANR french agency, Project ANR-TAMTAM N ANR-15-CE08-0008-01. Authors thanks also the ANR french agency, Project Labex CheMIsyst. The authors wish to acknowledge the support from the Chemistry Plateform of Campus in Montpellier (Plateform MEA University Montpellier), on which SEM and EDS have been performed. Authors thank Agnès Grandjean for fruitfull discussions. 


\section{References}

1. B. Said, T. Cacciaguera, F. Tancret, F. Fajula, A. Galarneau, Microporous Mesoporous Mater. 227 (2016) 176-190.

2. B. Said, A. Grandjean, Y. Barre, F. Tancret, F. Fajula, A. Galarneau, Microporous Mesoporous Mater. 232 (2016) 39-52.

3. A. Galarneau, Z. Abid, B. Said, Y. Didi, K. Szymanska, A. Jarzebski, F. Tancret, H. Hamaizi, A. Bengueddach, F. Di Renzo, F. Fajula, Inorganics 4 (2016) 9.

4. Z. Xue, J. Ma, W. Hao, X. Bai, Y. Kang, J. Liu, R. Li, J. Mater. Chem. 22 (2012) 25322538 .

5. M.W. Munthali, E. Johan, H. Aono, N. Matsue, J. Asian Ceram. Soc. 3 (2015) 245-250.

6. D. Alby, C. Charnay, M. Heran, B. Prelot, J. Zajac, J. Hazard. Mater. 344 (2018) 511-530.

7. T. Nenoff, J. L. Krumhansl, Solvent Extract. Ion Exch. 30 (2012) 33-40.

8. W. Baek, S. Ha, S. Hong, S. Kim, Y. Kim, Microporous Mesoporous Mater. 264 (2018) $159-166$.

9. Y. Yang, N. Burke, J. Zhang, S. Lim, Y. Zhu, RSC Adv. 4 (2014) 7279-7287.

10. H. S. Sherry, J. Phys. Chem. 70 (1966) 1158-1168.

11. P. K. Sinha, P. K. Panicker, R. V. Amalraj, V. Krishnasamy, Waste Manag. 15 (1995) 149-157.

12. H. Aono, R. Takahashi, Y. Itagaki, E. Johan, N. Matsue, J. Nuclear Mater. 508 (2018) 2025 .

13. P. K. Sinha, P.M. Sayasai, R. Shankar, R. Muthiah, S. Bera, S.V. Narasimhan, A.N. Pandey, A. Jaleel, J. Radioanal. Nucl. Chem. 242 (1999) 341-348.

14. H.-C. zur Loye, T. Besmann, J. Amoroso, K. Brinkman, A. Grandjean, C. H. Henager, S. Hu, S. T. Misture, S. R. Phillpot, N. B. Shustova, H. Wang, R. J. Koch, G. Morrison, E. Dolgopolova, Chem. Mater. 30 (2018) 4475-4488.

15. C. Cabaud, Y. Barré, L. De Windt, S. Gill, E. Dooryhée, M. P. Moloney, N. Massoni, A. Grandjean, Adsorption (2019) 1-7. https://doi.org/10.1007/s10450-019-00040-6

16. I. Bokor, S. Sdraulig, P. Jenkinson, J. Madamperuma, P. Martin, J. Environ. Radioact.151 (2016) 530-536.

17. C. Michel, Y. Barre, L. De Windt, C. de Dieuleveult, E. Brackx, A. Grandjean, J. Environ. Chem. Eng. 5 (2017) 810-817.

18. C. Michel, Y. Barre, M. Ben Guiza, C. de Dieuleveult, L. De Windt, A. Grandjean, Chem. Eng. J. 339 (2018) 288-295. 
19. Y. Didi, B. Said, T. Cacciaguerra, K. L. Nguyen, V. Wernert, R. Denoyel, D. Cot, W. Sebai, M.-P. Belleville, J. Sanchez-Marcano, F. Fajula, A. Galarneau, Microporous Mesoporous Mater. 281 (2019) 57-65.

20. P. Boscaro, T. Cacciaguerra, D. Cot, F. Fajula, V. Hulea, A. Galarneau, Microporous Mesoporous Mater. 280 (2019) 37-45.

21. A. Galarneau, A. Sachse, B. Said, C. H. Pelisson, P. Boscaro, N. Brun, L. Courtheoux, N. Olivi-Tran, B. Coasne, F. Fajula, F., C. R. Chimie 19 (2016) 231-247.

22. X. Zhang, D. Tang, M. Zhang, Powder Technol. 235 (2013) 322-328.

23. I. Langmuir, J. Amer. Chem. Soc., 40 (1918) 1361-1403.

24. P.S. Ghosal, A.K. Gupta, J. Molec. Liquids 225 (2017) 137-146.

25. K.-Y. Lee, M. Park, J. Kim, M. Oh, E-H. Lee, K-W. Kim, D-Y. Chung, J-K. Moon, Chemosphere 150 (2016) 765-771.

26. H. C. Thomas, J. Am. Chem. Soc. 66 (1944) 1664-1666.

27. Z. Yu, T. Qi, J. Qu, Y. Guo, Hydrometallurgy 158 (2015) 165-171. 
Table 1. Characteristic of the FAU-X adsorbents use for Cs capture.

\begin{tabular}{lllll}
\hline Adsorbents & $\begin{array}{l}\mathrm{D}_{\text {particle }} \\
(\mu \mathrm{m})\end{array}$ & $\begin{array}{l}\mathrm{D}_{\text {macro }} \\
(\mu \mathrm{m})\end{array}$ & $\begin{array}{l}\mathrm{V}_{\text {mic }} \\
(\mathrm{mL} / \mathrm{g})\end{array}$ & $\begin{array}{l}\mathrm{D}_{\text {crystals }} \\
(\mathrm{nm})\end{array}$ \\
\hline Monolith FAU-X-1 (nano) & & 2 & 0.30 & $150-200 / 600-800$ \\
Monolith FAU-X-2 (nano) & & 20 & 0.30 & $150-200 / 800-900$ \\
Monolith FAU-X-3 (micro) & & 2 & 0.33 & $1000-1500$ \\
Particles FAU-X-1(low agg.) & $800-1000$ & $0.1-0.4$ & 0.32 & $100-200 / 400-500$ \\
Particles FAU-X-2 (high agg.) & $800-1000$ & none & 0.29 & $500-700$ \\
\hline
\end{tabular}

Table 2. Chemical analysis by EDS of adsorbents (unwashed samples) after Cs capture (Cs EDS) in batch for $24 \mathrm{~h}$ with [CsOAc] $=3.59 \mathrm{mmol} / \mathrm{L}$ in mineral water (Evian), adsorbent 0.5 $\mathrm{g} / \mathrm{L}$. Comparison with CEC (Cs) from supernatant analysis.

\begin{tabular}{|c|c|c|c|c|}
\hline Adsorbents & $\mathrm{Si} / \mathrm{Al}$ & Atomic composition after Cs capture & $\begin{array}{l}\text { Cs } \\
\mathrm{meq} / \mathrm{g}\end{array}$ & $\begin{array}{l}\text { Cs EDS } \\
\mathrm{meq} / \mathrm{g}_{\text {final }}\end{array}$ \\
\hline $\begin{array}{l}\text { Monolith } \\
\text { FAU-X-1 }\end{array}$ & 1.28 & $\mathrm{Na}_{5.62} \mathrm{Mg}_{2.99} \mathrm{~K}_{0.17} \mathrm{Ca}_{26.74} \mathrm{Cs}_{13.64} \mathrm{Al}_{84} \mathrm{Si}_{108}$ & 1.75 & 1.62 \\
\hline $\begin{array}{l}\text { Monolith } \\
\text { FAU-X-3 }\end{array}$ & 1.46 & $\mathrm{Na}_{6.0} \mathrm{Mg}_{2.6} \mathrm{~K}_{0.4} \mathrm{Ca}_{32} \mathrm{Cs}_{17} \mathrm{Al}_{78} \mathrm{Si}_{114}$ & 1.0 & 1.82 \\
\hline $\begin{array}{l}\text { Particles } \\
\text { FAU-X-1 }\end{array}$ & 1.49 & $\mathrm{Na}_{6.2} \mathrm{Mg}_{2.8} \mathrm{~K}_{0.3} \mathrm{Ca}_{26.7} \mathrm{Cs}_{16.33} \mathrm{Al}_{77} \mathrm{Si}_{115}$ & 1.0 & 1.84 \\
\hline $\begin{array}{l}\text { Particles } \\
\text { FAU-X-2 }\end{array}$ & 1.39 & $\mathrm{Na}_{6.4} \mathrm{Mg}_{2.6} \mathrm{~K}_{0.4} \mathrm{Ca}_{27} \mathrm{Cs}_{16 . .5} \mathrm{Al}_{80} \mathrm{Si}_{111}$ & 1.0 & 1.86 \\
\hline
\end{tabular}


Table 3. $\mathrm{Cs}^{+}$adsorption properties in batch of FAU-X monoliths and particles fitted by the Langmuir model with solutions of $\mathrm{CsNO}_{3}$ in mineral water.

\begin{tabular}{llll}
\hline Adsorbents & $\begin{array}{l}\mathrm{K}_{\mathrm{L}} \\
(\mathrm{L} / \mathrm{meq})\end{array}$ & $\begin{array}{l}\mathrm{Q}_{\mathrm{m}} \\
(\mathrm{meq} / \mathrm{g})\end{array}$ & $\begin{array}{l}\text { Correlation } \\
\text { coefficient } \mathrm{R}^{2}\end{array}$ \\
\hline Monolith FAU-X-1 & 3.46 & 0.96 & 0.995 \\
Particles FAU-X-1* & 3.31 & 1.01 & 0.999 \\
Particles FAU-X-2 & 4.06 & 0.82 & 0.998 \\
\hline
\end{tabular}

* fit performed without the lowest equilibrium concentration for FAU-X-1

Table 4. Dynamic adsorption kinetic constants $\mathrm{K}_{\mathrm{th}}$ of $\mathrm{Cs}^{+}$and bed capacities Q (efficient, half, maximum of breakthrough curves) of Monolith FAU-X-2 $(0.5 \times 2.4 \mathrm{~cm}, \mathrm{~m}=0.181 \mathrm{~g})$ with $[\mathrm{CsOAc}]=0.5 \mathrm{mmol} / \mathrm{L}$ in mineral water. Comparison with literature data [18] for benchmark Cu-HCF@ $\mathrm{SiO}_{2}$.

\begin{tabular}{lllll}
\hline & $2^{\text {nd }}$ Capture & $3^{\text {rd }}$ Capture & $4^{\text {th }}$ Capture & $\begin{array}{l}\mathrm{Cu}- \\
\text { HCF } @ \mathrm{SiO}_{2}\end{array}$ \\
\hline Flow $(\mathrm{mL} / \mathrm{min})$ & 0.5 & 0.5 & 1.0 & \\
Flow $(\mathrm{m} / \mathrm{h})$ & 1.5 & 1.5 & 3.0 & 2.0 \\
$\mathrm{~K}_{\text {th }}(\mathrm{mL} / \mathrm{mg} / \mathrm{min})$ & 1.60 & 1.60 & 1.92 & \\
$\mathrm{Q}_{\text {bed }}(\mathrm{mg} / \mathrm{g})$ & 43.8 & 49.3 & 46.8 & \\
$\mathrm{Q}_{\text {bed }}(\mathrm{meq} / \mathrm{g})$ & 0.33 & 0.37 & 0.35 & \\
$\mathrm{Q}_{\text {eff }}(\mathrm{mL} / \mathrm{mL})$ & 191 & 224 & 191 & 230 \\
$\mathrm{Q}_{\text {eff }}(\mathrm{meq} / \mathrm{g})$ & 0.25 & 0.29 & 0.25 & 0.17 \\
$\mathrm{Q}_{\text {half }}(\mathrm{mL} / \mathrm{mL})$ & 255 & 278 & 260 & 250 \\
$\mathrm{Q}_{\text {half }}(\mathrm{meq} / \mathrm{g})$ & 0.33 & 0.36 & 0.25 & 0.18 \\
$\mathrm{Q}_{\max }(\mathrm{mL} / \mathrm{mL})$ & 287 & 331 & 311 & 300 \\
$\mathrm{Q}_{\max }(\mathrm{meq} / \mathrm{g})$ & 0.37 & 0.43 & 0.40 & 0.22 \\
\hline
\end{tabular}




\section{Figure Captions}

Figure 1. SEM pictures of Monolith FAU-X build with nanocrystals of macropore diameter $20 \mu \mathrm{m}$ (Monolith-FAU-X-2).

Figure 2. XRD pattern of Monolith FAU-X build with nanocrystals of macropore diameter 20 $\mu \mathrm{m}$ (Monolith-FAU-X-2).

Figure 3. Nitrogen adsorption/desorption isotherm at $77 \mathrm{~K}$ of Monolith FAU-X build with nanocrystals of macropore diameter $20 \mu \mathrm{m}$ (Monolith-FAU-X-2).

Figure 4. SEM pictures of FAU-X particles build with nanocrystals: (a) Particles-FAU-X-1 with low nanocrystals aggregation and (b) Particles-FAU-X-2 with high nanocrystals aggregation.

Figure 5. Kinetic of $\mathrm{Cs}^{+}$adsorption in batch in mineral water with $[\mathrm{CsOAc}]=3.59 \mathrm{mmol} / \mathrm{L}$ and $0.5 \mathrm{~g} / \mathrm{L}$ adsorbents for: (square) Monolith-FAU-X-1, (circle) Particles-FAU-X-1 with low nanocrystals aggregation and (triangle) Particles-FAU-X-2 with high nanocrystals aggregation.

Figure 6. Adsorption isotherms of $\mathrm{Cs}^{+}$in batch in mineral water with $\left[\mathrm{CsNO}_{3}\right]=0.50$ and $0.74 \mathrm{mmol} / \mathrm{L}$ and [adsorbent] $=0.5$ and $1 \mathrm{~g} / \mathrm{L}$ after $1 \mathrm{~h}$ stirring for: (square) Monolith-FAU-X1, (circle) Particles-FAU-X-1 with low nanocrystals aggregation and (triangle) ParticlesFAU-X-2 with high nanocrystals aggregation. Langmuir fits are presented for (orange) Monolith-FAU-X-1 and (blue) Particles-FAU-X-2 with high nanocrystals aggregation.

Figure 7. Adsorption of $\mathrm{Cs}^{+}$in batch in deionized water with $\left[\mathrm{CsNO}_{3}\right]=0.50$ and 0.74 $\mathrm{mmol} / \mathrm{L}$ and [adsorbent] $=0.5$ and $1 \mathrm{~g} / \mathrm{L}$ after $1 \mathrm{~h}$ stirring for: (square) Monolith-FAU-X-1, (circle) Particles-FAU-X-1 with low nanocrystals aggregation and (triangle) Particles-FAU$\mathrm{X}-2$ with high nanocrystals aggregation.

Figure 8. Breakthrough curves of $\mathrm{Cs}^{+}$adsorption $[\mathrm{CsOAc}]=0.5 \mathrm{mmol} / \mathrm{L}$ in mineral water with Monolith-FAU-X-2 (macropore diameter $20 \mu \mathrm{m}$ ) for (black circles) $2^{\text {nd }}$ adsorption at 0.5 $\mathrm{mL} / \mathrm{min}(1.52 \mathrm{~m} / \mathrm{h})$, (blue circles) $3^{\text {rd }}$ adsorption at $0.5 \mathrm{~mL} / \mathrm{min}(1.52 \mathrm{~m} / \mathrm{h})$ and (red circles) $4^{\text {th }}$ 
adsorption at $1 \mathrm{~mL} / \mathrm{min}(3.04 \mathrm{~m} / \mathrm{h})$. (Grey squares) Data of benchmark $\mathrm{Cu}-\mathrm{HCF} @ \mathrm{SiO}_{2}$ taken from ref. 18. Lines are for eyes guide. 
Figure 1
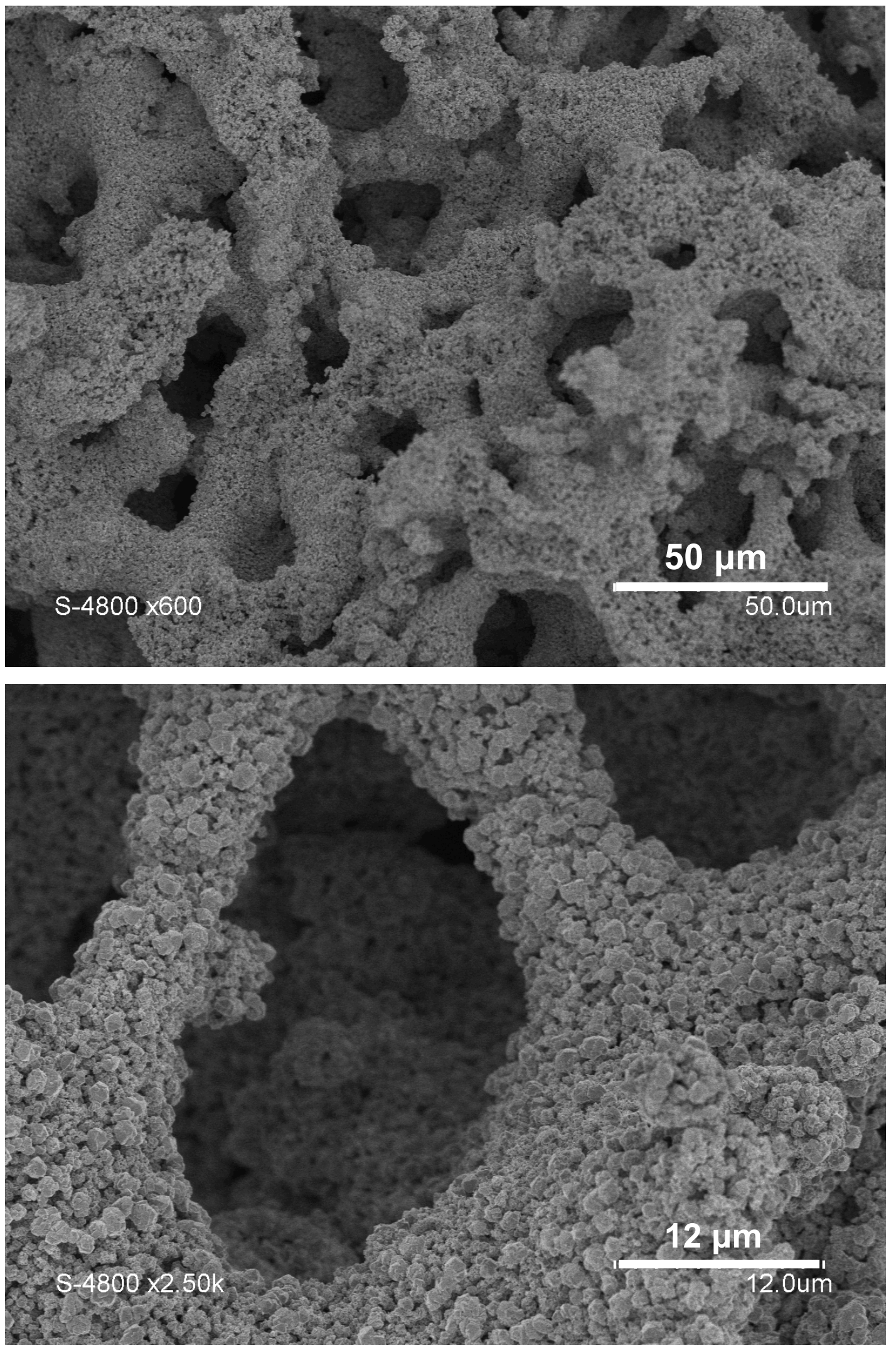


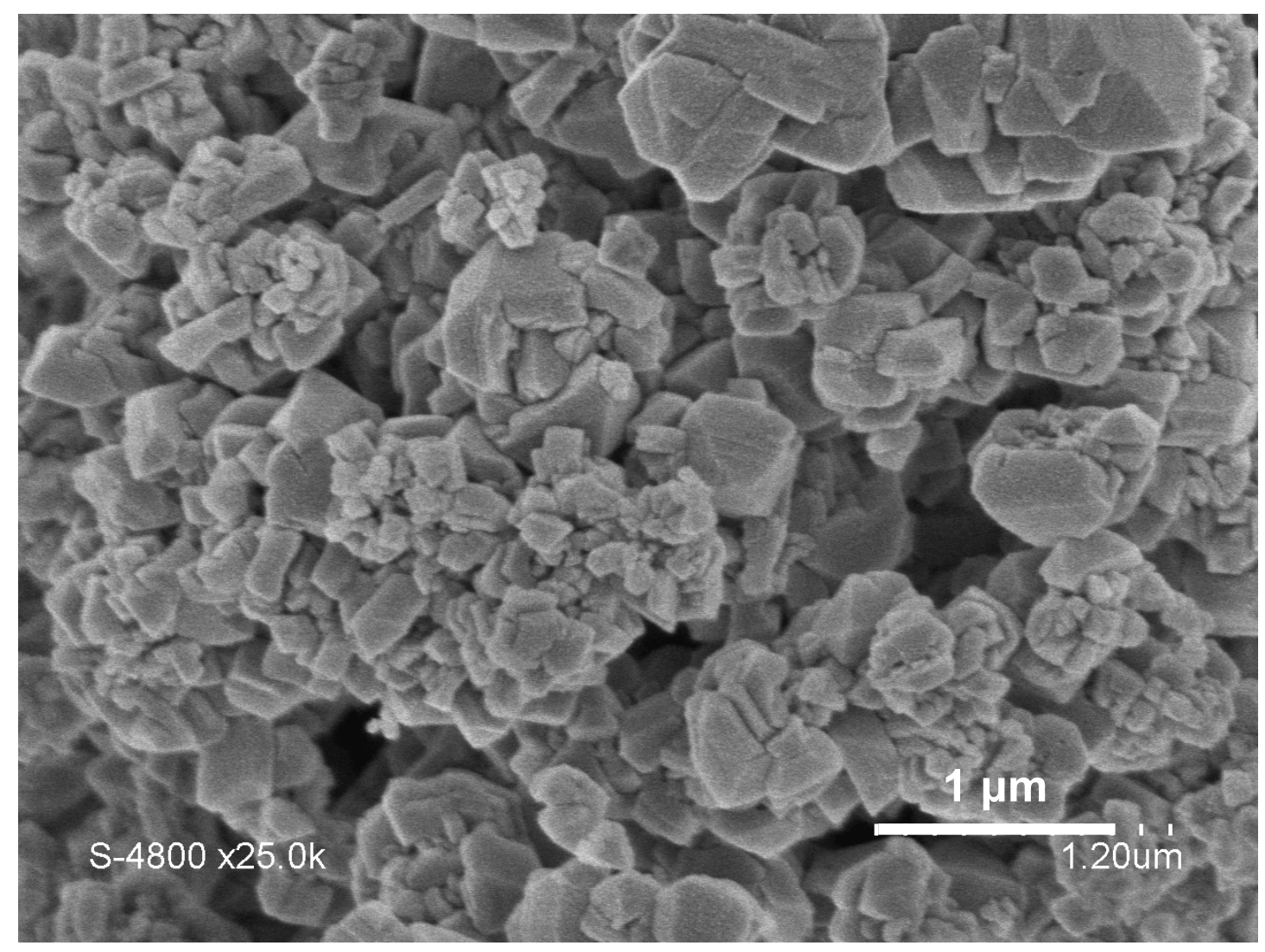


Figure 2

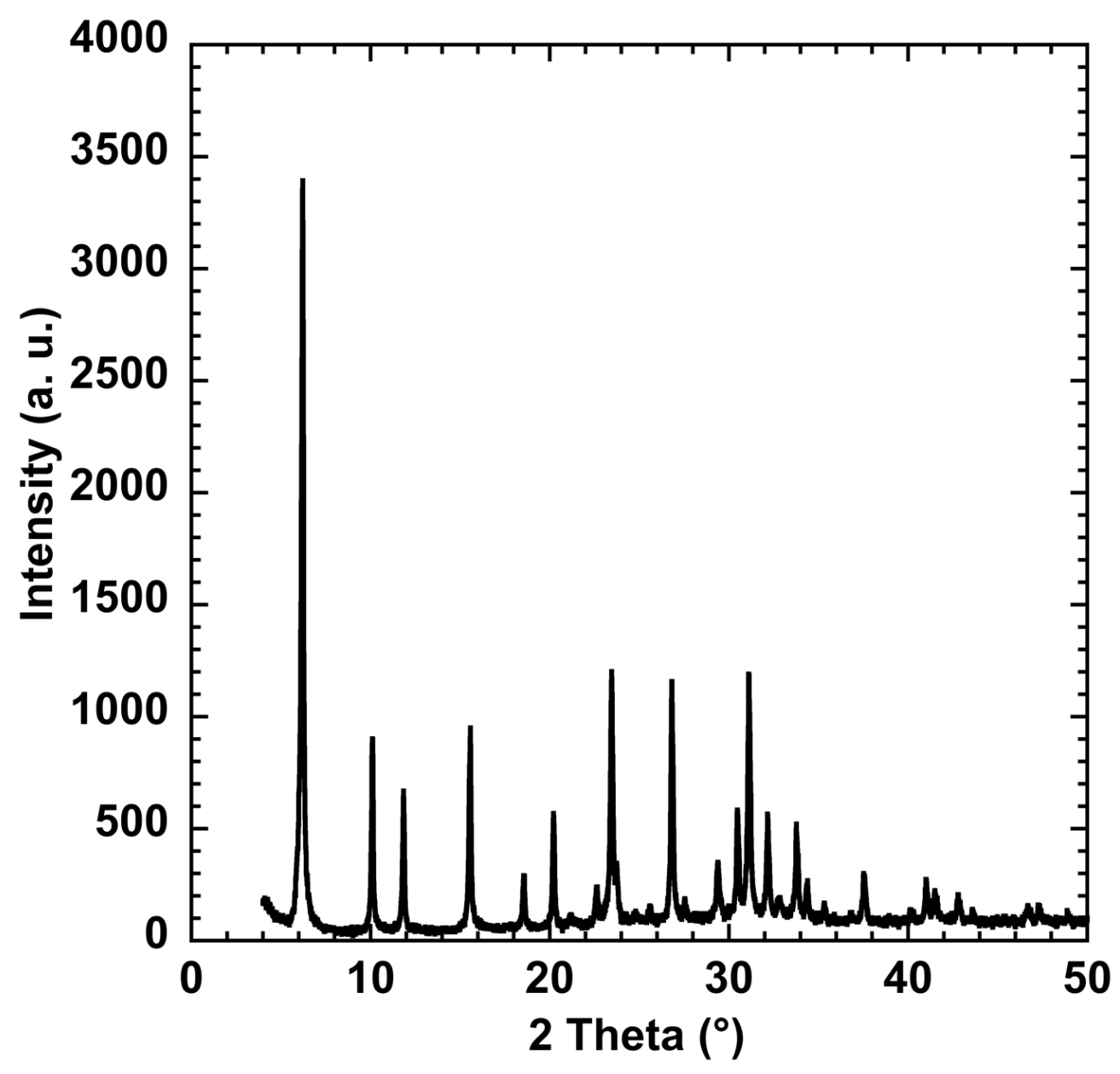


Figure 3

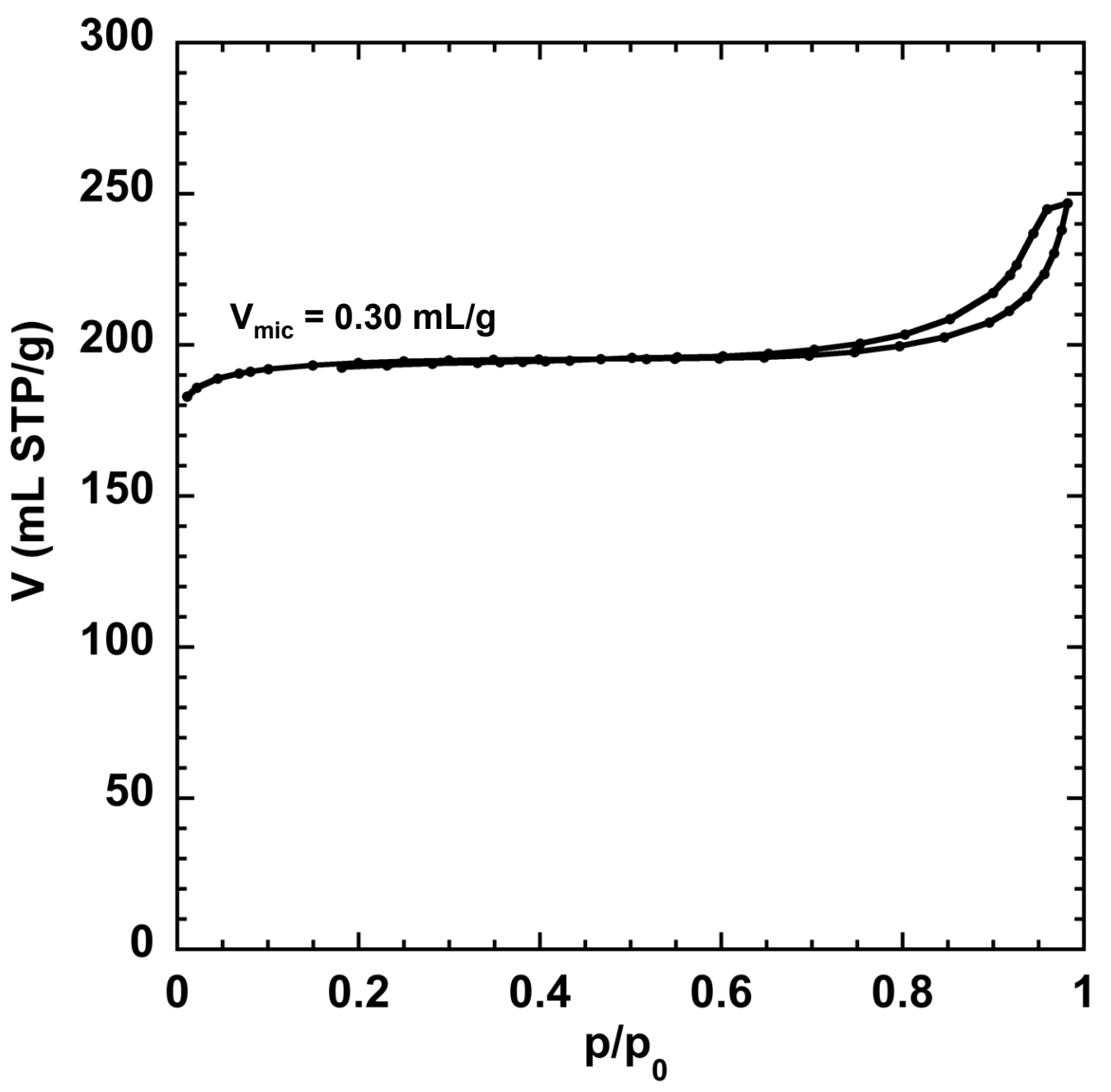




\section{Figure 4}
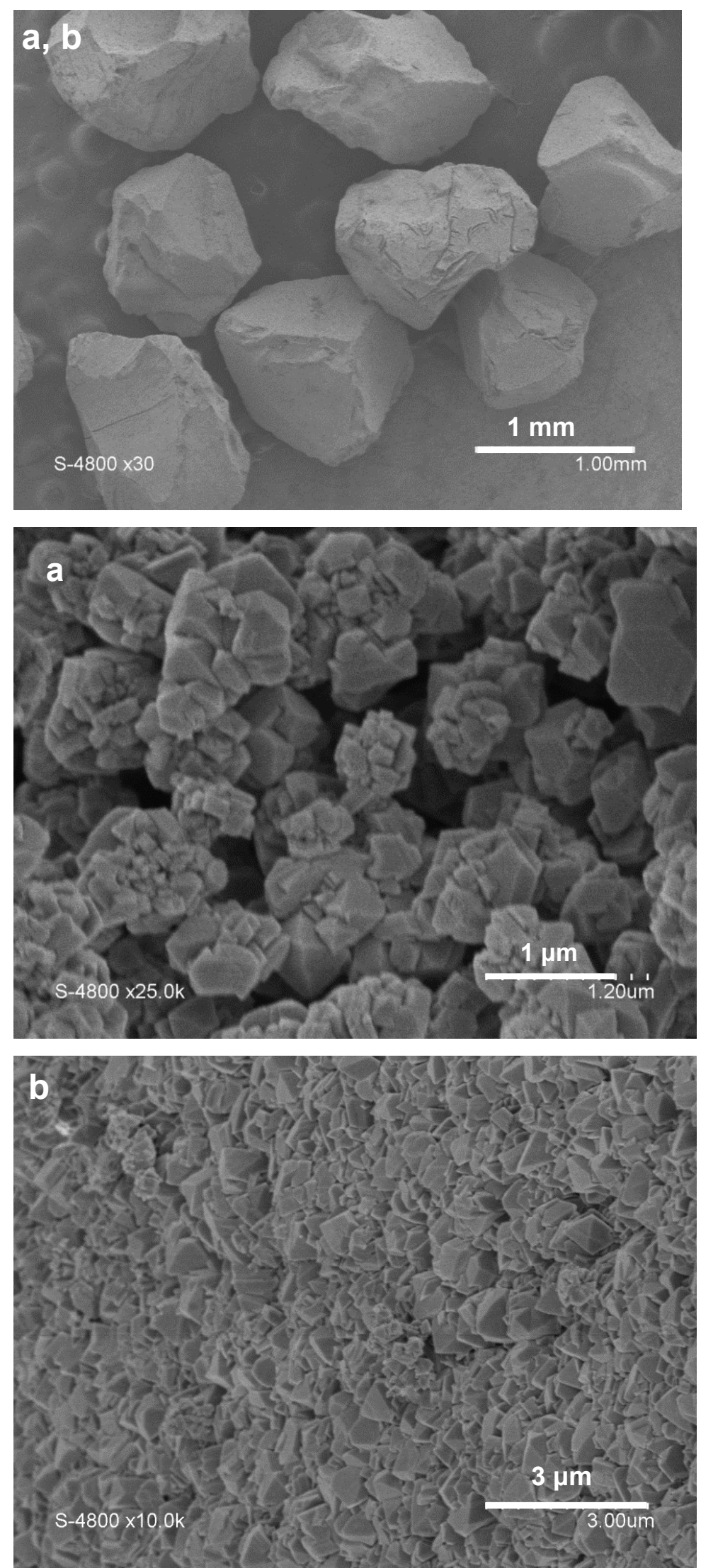
Figure 5

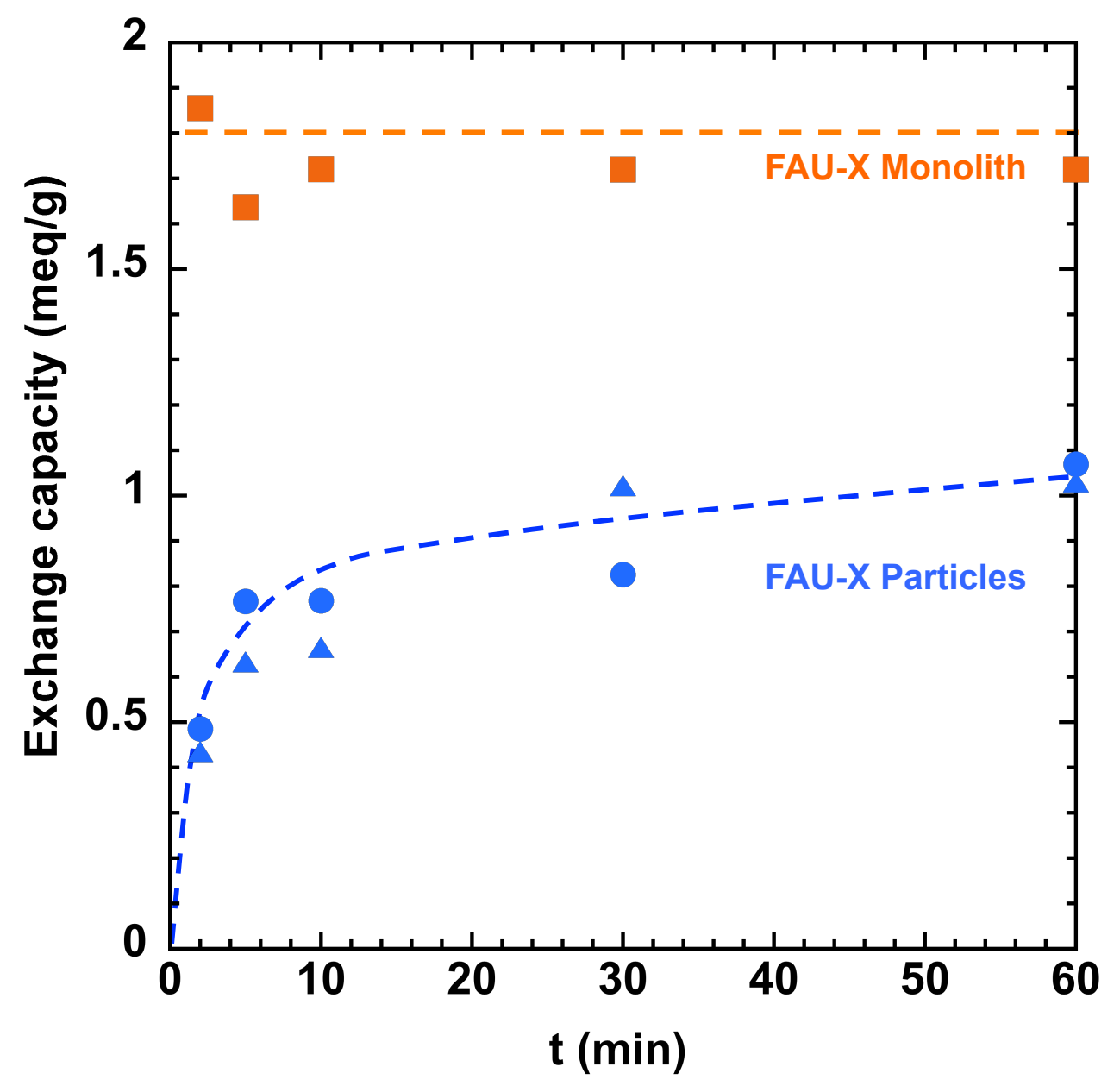


Figure 6

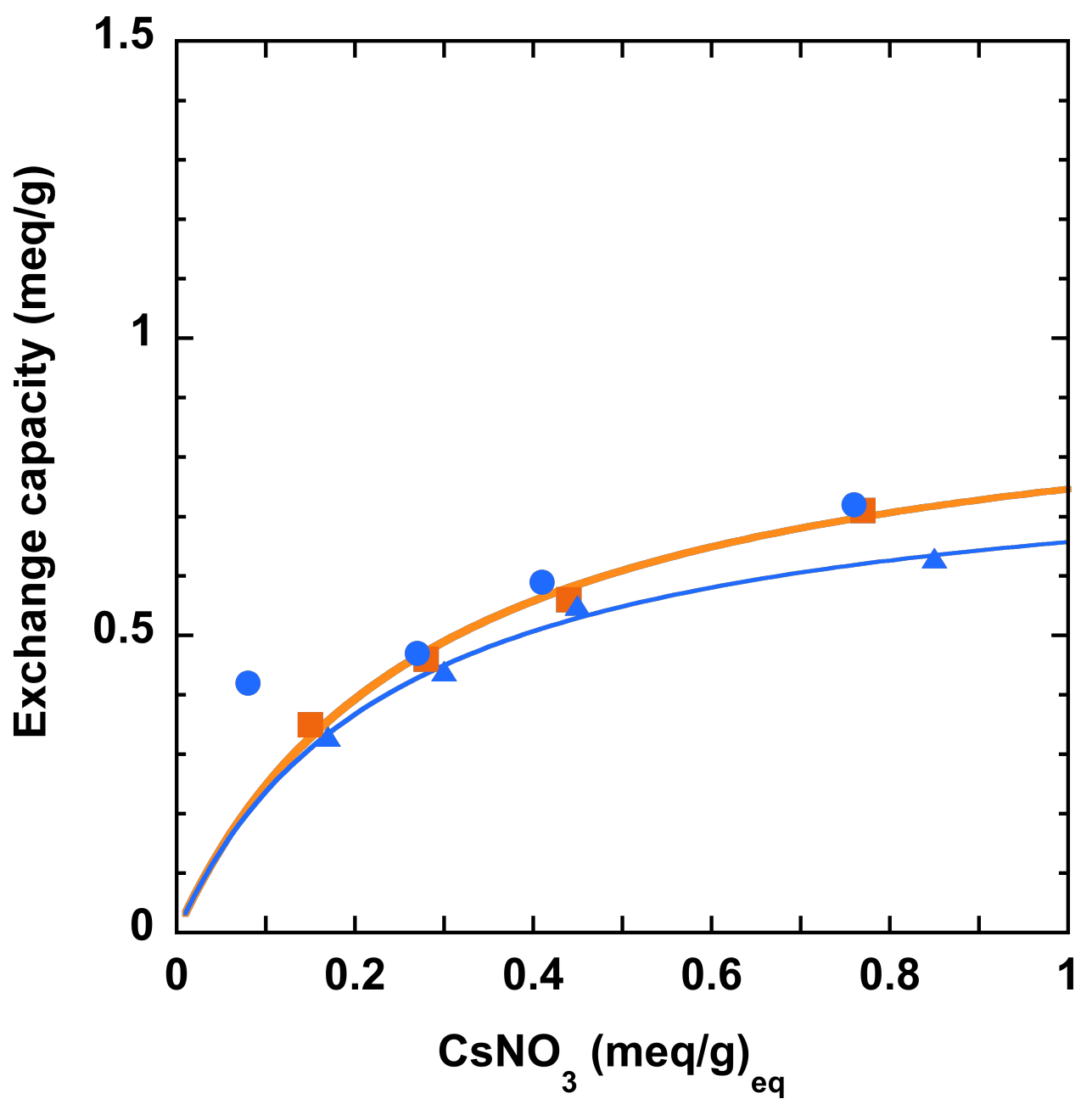


Figure 7

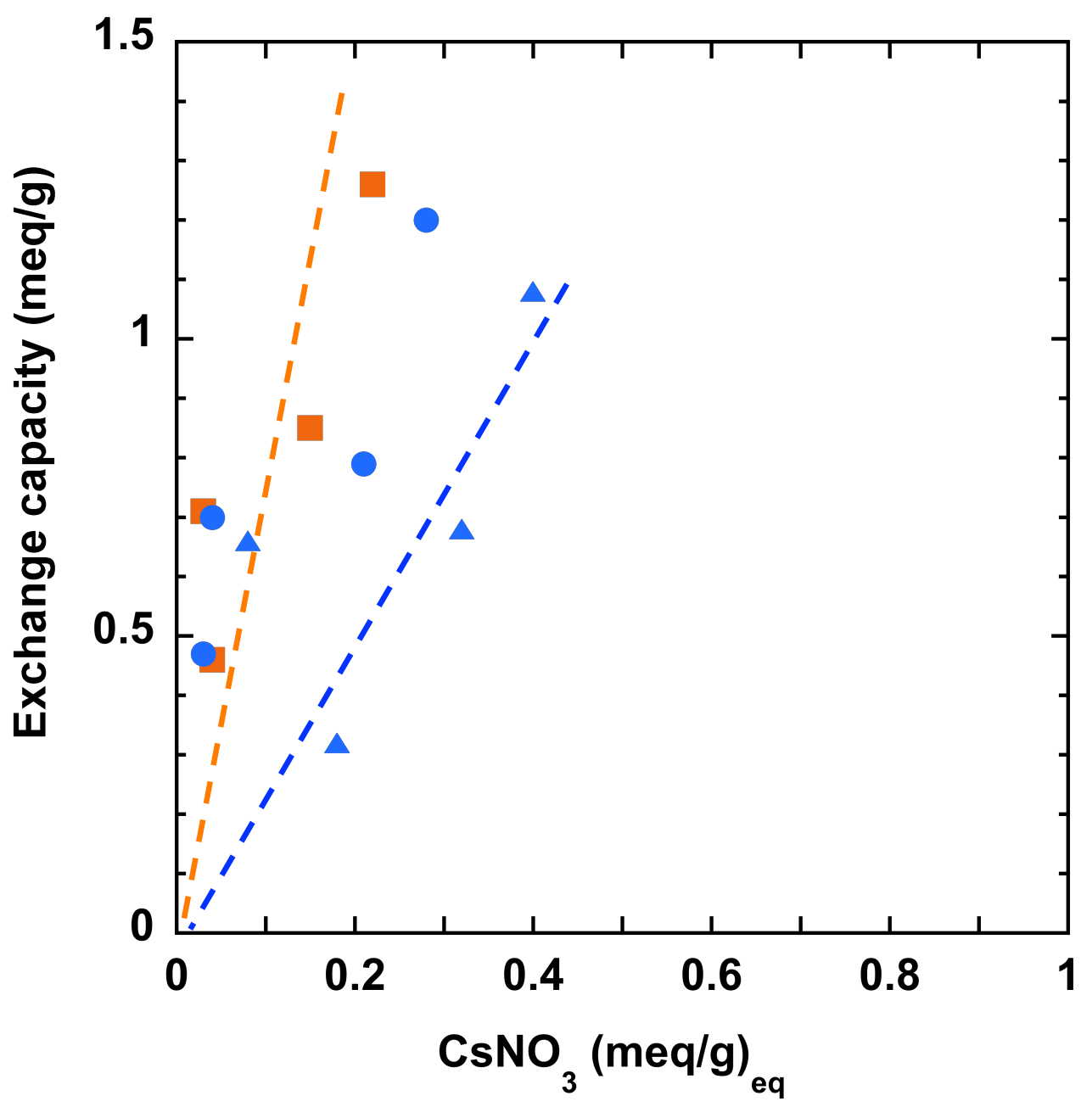


Figure 8

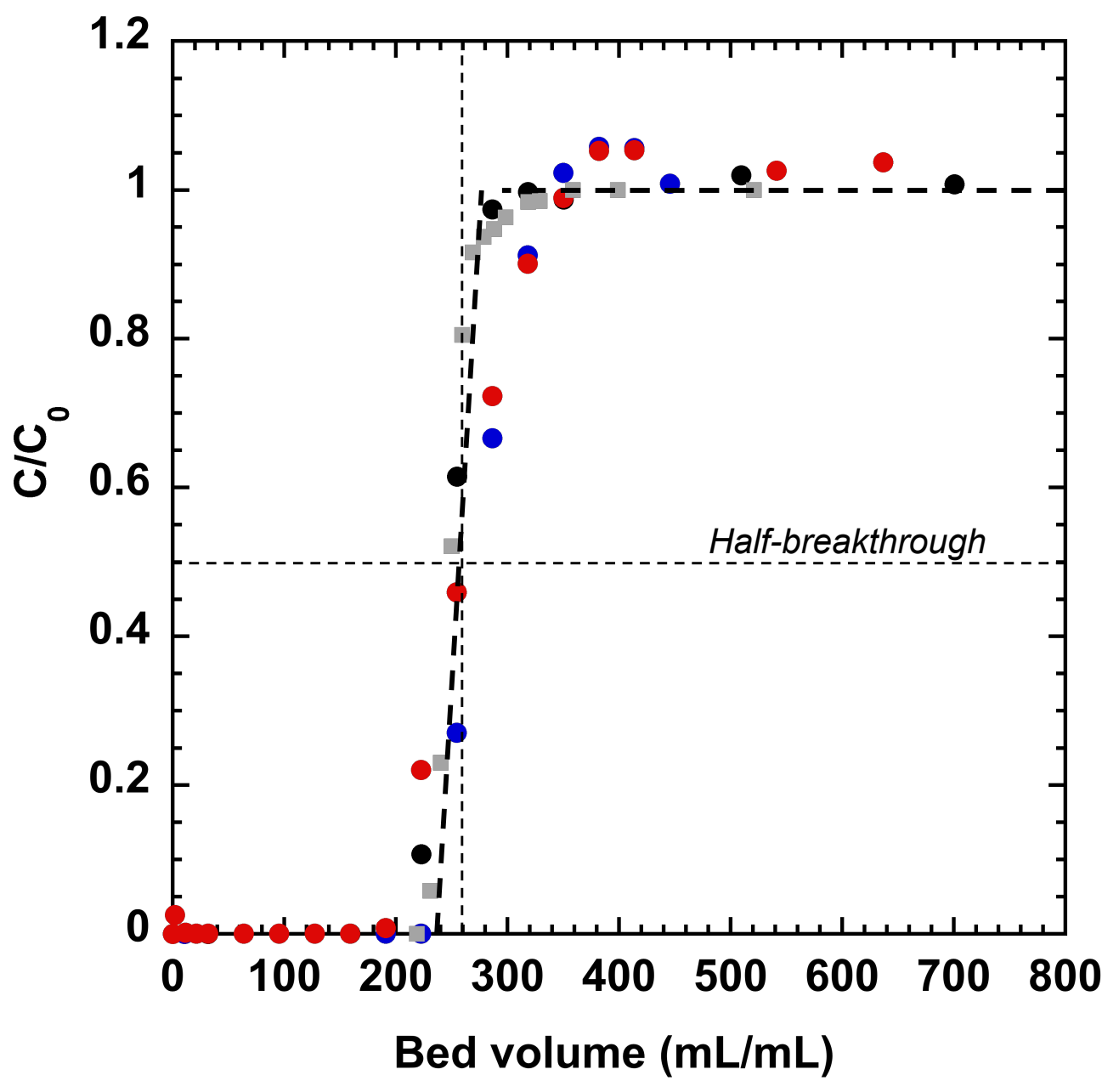




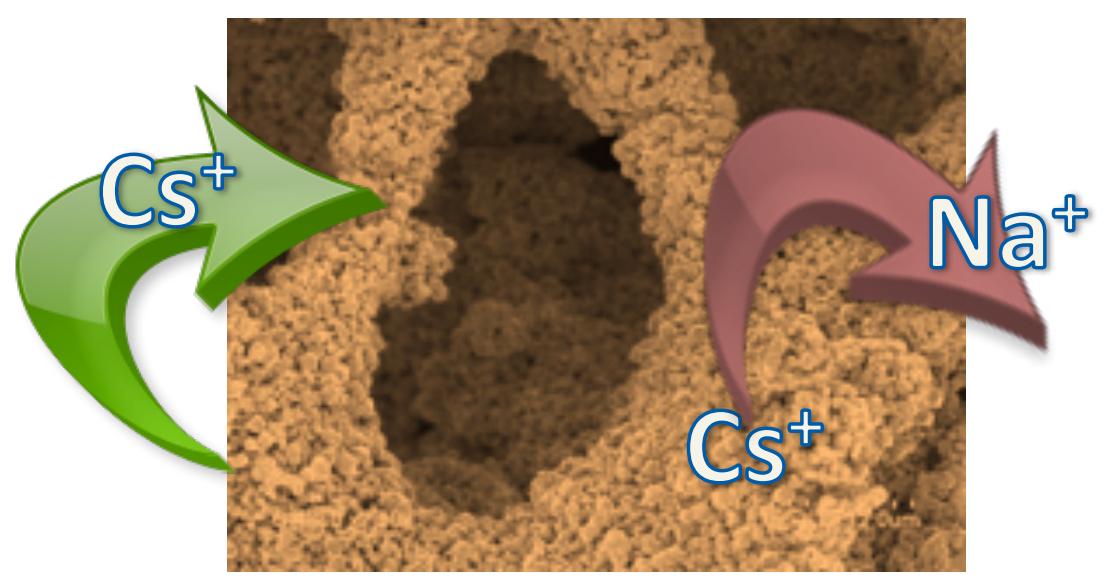

